\title{
Changes in benthic sediment conditions under an Atlantic salmon farm at a deep, well-flushed coastal site
}

\author{
R. J. Bannister ${ }^{1, *}$, T. Valdemarsen ${ }^{2}$, P. K. Hansen ${ }^{1}$, M. Holmer ${ }^{2}$, A. Ervik ${ }^{1}$ \\ ${ }^{1}$ Institute of Marine Research, PO Box 1870, 5817 Bergen, Norway \\ ${ }^{2}$ Institute of Biology, University of Southern Denmark, Campusvej 55, 5230 Odense M, Denmark
}

\begin{abstract}
Along the Norwegian coastline, it is predicted that salmonid aquaculture will rapidly expand in the coming years, exceeding current production levels of 1.3 million t in 2012. This will result in increased interactions with both local and regional environments, thus more knowledge is urgently needed to better risk-manage a rapid expansion. We investigated changes in the benthic sediment condition in association with an Atlantic salmon farm sited at a deep, well-flushed coastal site in western Norway. Benthic fluxes of $\mathrm{O}_{2}$, total carbon dioxide $\left(\mathrm{TCO}_{2}\right)$ and $\mathrm{NH}_{4}{ }^{+}$intensified over the production cycle, when farming activity and the sedimentation of carbon and nitrogen was at its maximum. During the sampling campaign, benthic fluxes of $\mathrm{O}_{2}, \mathrm{TCO}_{2}$ and $\mathrm{NH}_{4}{ }^{+}$at the farming location were higher than those measured at a nearby reference location. Stimulation of benthic fluxes over the production cycle at the farming location were most likely driven by changes in benthic faunal community structure, abundance and biomass. High abundances of opportunistic species (i.e. Capitella capitata, Heteromastus filiformis, Paramphinome jeffreysii, Abra nitida and Thyasira sarsii) dominated the farming location, whilst the sediment biogeochemistry was stable throughout the study period at both locations. However, despite differences in benthic fluxes and fauna structure over the production cycle, the input of organic carbon and nitrogen did not exceed the mineralisation capacity of a deep, well-flushed, fish farming location.
\end{abstract}

KEY WORDS: Atlantic salmon · Salmo salar $\cdot$ Sulphate reduction rates $\cdot$ Benthic impact · Organic enrichment $\cdot$ Sediment metabolism $\cdot$ Aquaculture $\cdot$ Fauna diversity

\section{INTRODUCTION}

Global aquaculture production (63.6 million $\mathrm{t}$ annually) accounts for more than $41 \%$ of total world fisheries (capture and production; FAO 2012), and is important for meeting the global demand for protein. In Norway, the production of salmonids using floating net cages has tripled since 1999, with annual production exceeding 1.3 million $t$ (Norwegian Directorate of Fisheries 2012). During this rapid expansion, the number of fish farms in Norway has decreased, while individual farm size and production levels have increased (Gullestad et al. 2011). This

\footnotetext{
*Corresponding author: raymond.bannister@imr.no
}

increase in site-specific production is raising concerns about the environmental impacts and longterm sustainability of this rapidly growing industry.

The intensive farming of fin fish in net pens releases organic and inorganic effluents (i.e. carbon, nitrogen and phosphorus) in the form of waste feed, faeces and metabolic by-products to the surrounding aquatic marine environments (Carroll et al. 2003, Holmer et al. 2005, Strain \& Hargrave 2005). Accumulation of these effluents can contribute to eutrophication and nutrient enrichment of pelagic systems and cause organic enrichment of the benthic environment (Strain \& Hargrave 2005). Organic enrich-

(C) The authors 2014. Open Access under Creative Commons by Attribution Licence. Use, distribution and reproduction are unrestricted. Authors and original publication must be credited. 
ment of benthic environments is commonly observed underneath fish farms, but the degree of enrichment and hence the environmental impact of fish farms is dependent on a number of factors, including the size of the farm (i.e. number of net pens and the biomass of fish), the physical conditions around the farming location (i.e. hydrodynamics and water depth) and the husbandry practices at the fish farm (Holmer et al. 2005).

Organic enrichment of shallow-water (<50 m deep) benthic systems due to fish farming modifies the biogeochemical processes in soft sediment habitats (Holmer \& Kristensen 1992, Holmer \& Frederiksen 2007, á Norði et al. 2011). Remineralisation of the highly labile organic waste (i.e. fish feed and faeces) results in increased sediment oxygen demand and altered metabolic pathways, and a shift from aerobic to anaerobic (i.e. sulphate reduction and methanogenesis) microbial degradation is frequently observed (Holmer \& Kristensen 1994, Holmer et al. 2003, Valdemarsen et al. 2009). Excessive organic enrichment due to fish farming can modify sediment conditions (Valdemarsen et al. 2012), which may change the composition and total biomass of benthic fauna communities (Kutti et al. 2007b, Hargrave et al. 2008).

In Norway, fish farms have relocated from shallow ( $<50$ m deep) sheltered embayments with low current velocities to deeper ( $>100 \mathrm{~m}$ deep), more exposed areas with higher current velocities, but the impact of fish farming at deep water locations has been poorly investigated. Relocating fish farms to deeper and more dynamic locations is thought to improve cultivation conditions, while at the same time, alleviate potential environmental impacts through increased dispersal of waste products (Cromey et al. 2002, Stigebrandt et al. 2004, Hansen \& Kryvi 2009, Holmer 2010) and increase the size of the farming footprint (Keeley et al. 2013a). Few studies have, however, investigated such impacts beneath deep-water fish farms. Kutti et al. (2007a) demonstrated that fish farming over deep-water locations (230 m deep) with moderate water currents ( 1 to $20 \mathrm{~cm} \mathrm{~s}^{-1}$ ) increases the dispersal of organic matter downstream from the fish farms. Thus, the benthic community structure can be affected on a much larger spatial scale (up to $500 \mathrm{~m}$ from the farming location) than observed for shallowwater farming locations (Kutti et al. 2007b, 2008). Recent evidence also suggests that the sediment chemistry may be severely impacted at deep-water, low-current (highest average measurement of $5.3 \mathrm{~cm}$ $\mathrm{s}^{-1}$ ) farming locations (Valdemarsen et al. 2012). However, studies of the benthic impact at deep- water farming locations are rare, and more studies are urgently needed to provide a holistic understanding of the impact of organic enrichment at deepwater farming sites.

In the present study, we aimed to investigate temporal-scale changes in total sediment metabolism, sediment metabolic pathways and benthic infauna community composition to establish a holistic understanding of the interaction of increased organic carbon deposition from fin-fish aquaculture at a wellflushed deep-water coastal site in a Norwegian fjord. We hypothesise that moderate water currents at this fish farming site will result in moderate organic enrichment of the seabed and less severe environmental impacts compared to poorly flushed fish farming locations (as seen in Valdemarsen et al. 2012).

\section{MATERIALS AND METHODS}

\section{Study sites}

The Hardanger fjord is a sill fjord (depth of sill: $150 \mathrm{~m}$ ) located on the west coast of Norway, $50 \mathrm{~km}$ south of Bergen (Fig. 1). The fjord is oriented in an east-west direction and has an average and maximum depth of 150 and $800 \mathrm{~m}$, respectively. The sill is relatively shallow and the fjord system is well flushed with well-oxygenated bottom water (Aure 2013).

The studied fish farm produced $2650 \mathrm{t}$ of Atlantic salmon Salmo salar between April 2009 to October 2010, with a biological food conversion ratio (FCR) of 1.4 (3870 t of feed). Fish biomass, feed rates and calculated release rates of organic wastes during the production period are presented in Table 1. The fish farm has been in operation at the same site for $7 \mathrm{yr}$, with a consistent cycle of 18 mo production and 6 mo fallowing. This equates to approximately $10000 \mathrm{t}$ of produced salmon and a total feed consumption of approximately $13000 \mathrm{t}$. The farm consisted of a cluster of 8 circular net pens covering a total area of $1146 \mathrm{~m}^{2}$. Each net pen had a $120 \mathrm{~m}$ circumference, was $40 \mathrm{~m}$ deep and was separated by $47 \mathrm{~m}$ distance to the neighbouring net pen. The water depth at the farm site was $180 \mathrm{~m}$. Our sampling location at the farm was downstream from the prevailing currents and was approximately 25 to $30 \mathrm{~m}$ from the edge of the net pen cluster to prevent entanglement with mooring lines, and was located at least $2 \mathrm{~km}$ from the nearest fish farm within the fjord. Using a box corer to collect undisturbed sediment cores limited our ability to sample randomly around the farming installation due to the heterogeneous benthic sub- 


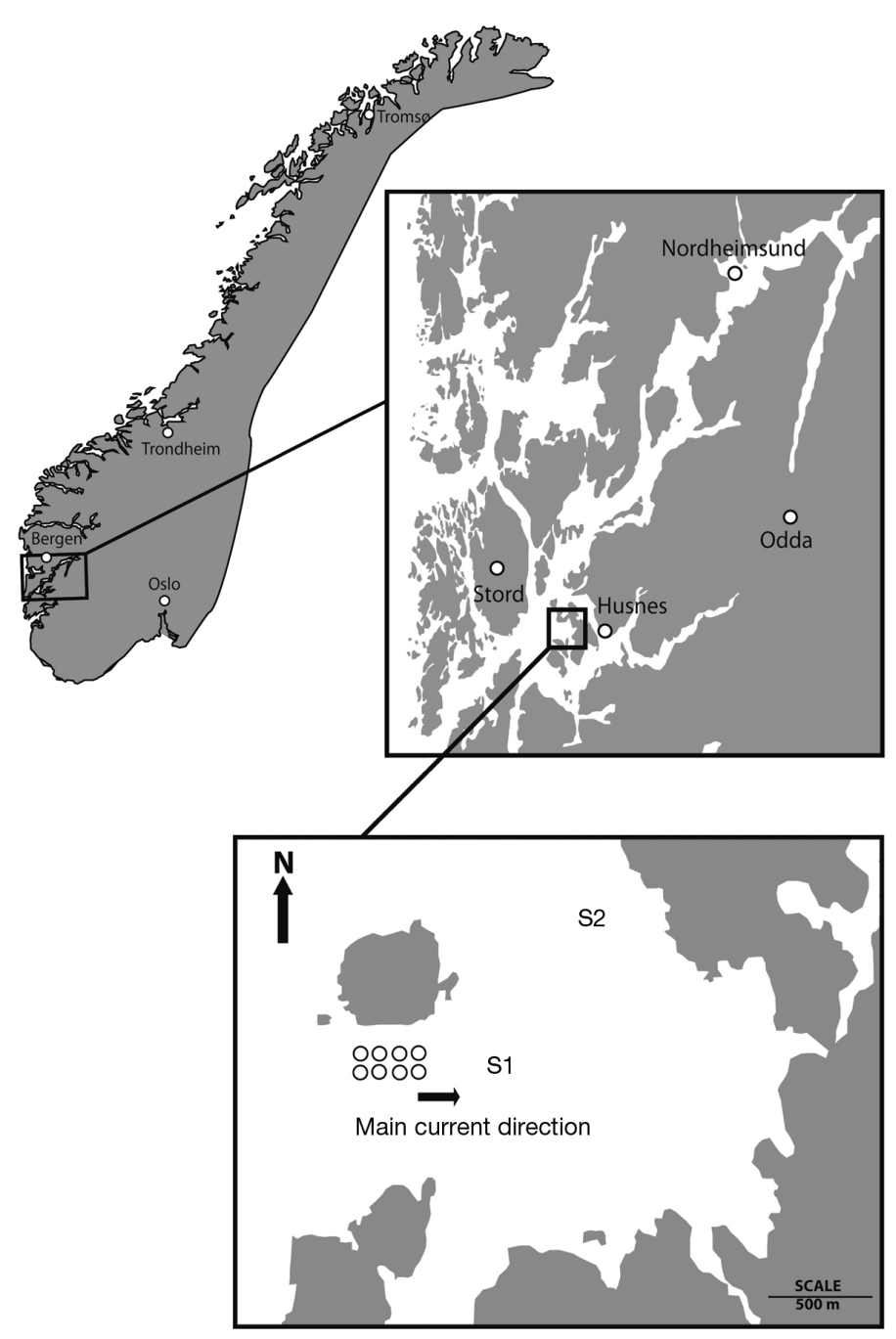

Fig. 1. Hardanger Fjord in Norway. The insets highlight the region where the studied salmon farm was located. S1:

farming location; S2: reference location; O: fish net pen

Table 1. Maximum standing biomass, average feeding rates and estimated release of particulate organic waste (POM) over the production cycle. POM release rates are based on Brooks \& Mahnken (2003) and suggest that faecal discharge corresponds to $8.8 \%$ of organic matter delivered via fish feed

\begin{tabular}{|lccc|}
\hline Period & $\begin{array}{c}\text { Biomass } \\
(\mathrm{t})\end{array}$ & $\begin{array}{c}\text { Feeding } \\
\text { (t of dry } \\
\left.\text { feed d }^{-1}\right)\end{array}$ & $\begin{array}{c}\text { POM } \\
\text { released } \\
\left(\mathrm{t} \mathrm{d}^{-1}\right)\end{array}$ \\
\hline Feb-May 2009 & 195 & 1.22 & 0.11 \\
Jun-Oct 2009 & 767 & 5.21 & 0.46 \\
Nov 2009-Feb 2010 & 1236 & 4.47 & 0.39 \\
Mar-Jun 2010 & 1747 & 6.18 & 0.54 \\
Jul-Sep 2010 & 2311 & 13.44 & 1.18 \\
Oct-Dec 2010 & 1839 & 5.90 & 0.52 \\
\hline
\end{tabular}

strate that varied from soft sediment to hard bedrock. Therefore, we were limited to random sampling along the eastern side of the fish farm to obtain suitable sediment cores.

The reference location used in this study was $700 \mathrm{~m}$ northeast from the fish farm, and was oriented downstream relative to the prevalent current direction from the farm. The $700 \mathrm{~m}$ distance from the farm to the reference site was chosen based on the study by Kutti et al. (2007a), who showed that the effects of elevated sedimentation of organic waste on infauna communities from fish farms is only detectable $500 \mathrm{~m}$ away from farming locations. Furthermore, finding suitable reference locations more than $700 \mathrm{~m}$ from the farming location were impossible due to the local environment (i.e. variable bathymetry and rocky bottom substrate), our sampling equipment (box corer) and interference from neighbouring fish farms. The water depth at the reference site was approximately $170 \mathrm{~m}$.

\section{Temporal resolution of measurements}

To determine changes in sediment benthic condition, 4 sampling campaigns were conducted over a 12 mo period. The first and second sampling, in March and June 2010, occurred 11 mo and 14 mo into the production cycle of the farm, when feeding intensity and waste production was intermediate. The third sampling occurred in September 2010 and was performed near the end of the production cycle, when feeding intensity was close to maximum (Table 1). The last sampling period (February 2011) was carried out 2.5 mo after the production cycle had ended (i.e. during the fallowing period).

\section{Hydrodynamics and sedimentation}

Current velocity and sedimentation of particulate matter were measured at both sites on 4 occasions in 2010-11 during the period of benthic sampling. On every sampling occasion, moorings were deployed at the fish farm and reference locations, consisting of 2 cylindrical sediment traps (length $58 \mathrm{~cm}$ and diameter $9.6 \mathrm{~cm}$ ) and current meters (SD-6000 MINI Current Meter, Sensor Data A/S) placed 10 and $80 \mathrm{~m}$ above the bottom. Before deployment, sediment traps were filled with filtered $(100 \mu \mathrm{m})$ seawater and $500 \mathrm{ml}$ of $4 \%$ buffered formalin to prevent decomposition of trapped organic material. Sediment traps and current meters were deployed for $7,22,23$ and $12 \mathrm{~d}$ in 
March, June, September and February, respectively. Mean, minimum and maximum current speeds as well as main current direction were obtained.

The total mass and sedimentation rates of trapped material was determined from replicate subsamples filtered onto pre-combusted and pre-weighed Whatman GF/F filters as described in Kutti et al. (2007a). Filters were analysed for total particulate matter (TPM), particulate organic carbon (POC) and total nitrogen (TN). TPM was determined as the dry material retained on filters ( $\mathrm{n}=3$, dried at $105^{\circ} \mathrm{C}$ for $24 \mathrm{~h}$ ). Replicate filter samples $(\mathrm{n}=3)$ were exposed to $\mathrm{HCl}$ fumes overnight to remove inorganic $\mathrm{C}$, and afterwards, POC and TN of trapped material was determined by elemental analysis on a Carlo Erba NCS 2500 Elemental Analyser, following standardised procedures (Kristensen \& Andersen 1987). Due to lost equipment, water currents and sedimentation rates were not measured at the reference site in June.

\section{Collection of sediment}

Six box-cores $(30 \mathrm{~cm} \times 45 \mathrm{~cm} \times 45 \mathrm{~cm})$ were used to retrieve undisturbed sediment from both the farming and reference sites during the 4 sampling occasions. From each box-core, one $12 \mathrm{~cm}$ deep sediment subcore was sampled with a polycarbonate core liner (length and diameter 30 and $10 \mathrm{~cm}$, respectively). Bottom water, collected from $10 \mathrm{~m}$ above the bottom with a Niskin water sampler, was gently added to the top of sediment cores. Each core was sealed at both ends with rubber stoppers placed in insulated cooler boxes $\left(8\right.$ to $\left.9^{\circ} \mathrm{C}\right)$ and transported to the deep-sea ecology laboratory at the Institute of Marine Research (IMR), Bergen, for further analysis.

\section{Benthic fluxes}

In the laboratory, the sediment cores were placed in a tank containing seawater $\left(8\right.$ to $\left.9^{\circ} \mathrm{C}\right)$. The water level of the tank was below the top rim of the sediment cores and was maintained at a constant level via an overflow. Each sediment core was individually supplied with 8 to $9^{\circ} \mathrm{C}, 1.0 \mu \mathrm{m}$ filtered seawater through $0.5 \mathrm{~cm}$ diameter silicone tubing at a rate of $250 \mathrm{ml} \mathrm{min} \mathrm{m}^{-1}$ from a header tank setup with a flowthrough seawater system to maintain independence between sediment cores.

Fluxes of total carbon dioxide $\left(\mathrm{TCO}_{2},\right)$, ammonium $\left(\mathrm{NH}_{4}{ }^{+}\right)$and oxygen $\left(\mathrm{O}_{2}\right)$ were determined on the 6 sediment cores after $2 \mathrm{~d}$ of acclimatisation, with the exception of March 2010 and February 2011, when only 5 sediment cores were retrieved. After taking initial water samples from the headspace in each sediment core, gas-tight lids equipped with motordriven stirring bars (150 rpm) were fitted. Sediment cores from the farming and reference locations were incubated for 3 to $4 \mathrm{~h}$ and 14 to $16 \mathrm{~h}$, respectively, before final water samples were collected. Samples for $\mathrm{TCO}_{2}$ and $\mathrm{NH}_{4}{ }^{+}$were stored and analysed as described in 'Sample preservation, storage and analysis' below. The $\mathrm{O}_{2}$ concentration change during flux incubations was determined with a FIBOX $\mathrm{O}_{2}$ microoptode (PreSens).

\section{Core slicing}

Three sediment cores from every location were sliced into 6 sediment slices covering the depth intervals $0-1,1-2,2-4,4-6,6-8$ and $8-10 \mathrm{~cm}$ for extraction of pore water and solid-phase measurements on every sampling occasion. Subsequently, each sediment slice was homogenised, and sediment subsamples were taken for determination of water content, sediment density and POC and TN content. In March and September 2010, additional samples were taken for reactive Fe extraction, acid volatile sulphides (AVS) and chromium reducible sulphides (CRS). Approximately $30 \mathrm{ml}$ of homogenised sediment was transferred to tubes and centrifuged for $10 \mathrm{~min}$ at $1500 \mathrm{rpm}$ (453 g). Pore water was sampled as supernatant after centrifugation. Samples were taken for determination of $\mathrm{TCO}_{2}$, $\mathrm{NH}_{4}{ }^{+}$, sulphate $\left(\mathrm{SO}_{4}{ }^{2-}\right)$ and total hydrogen sulphide $\left(\mathrm{TH}_{2} \mathrm{~S}\right)$ analysis as described below. The remaining sediment was used for microbial reaction rates (sealed jar experiments, see 'Sample preservation, storage and analysis' below).

\section{Sediment characteristics}

Sediment density was determined by measuring the weight of a known volume of wet sediment. Sediment water content was determined as the weight loss of wet sediment after drying $(48 \mathrm{~h}$ at $60^{\circ} \mathrm{C}$ ). Sediment content of POC and TN was analysed on dry sediment subsamples on a Carlo Erba CHN EA1108 Elemental Analyser according to Kristensen \& Andersen (1987). Grain size distribution was determined using a Coulter LS Particle Size Analyser, with data on the median grain size presented. 


\section{Extraction of reactive $\mathrm{Fe}(\mathrm{II})$ and $\mathrm{Fe}(\mathrm{III})$}

Reactive solid-phase Fe(II) and Fe(III) (RFe(II) and $\mathrm{RFe}(\mathrm{III})$ ) was extracted from $\sim 0.3 \mathrm{~g}$ sediment subsamples that were transferred to pre-weighed centrifuge tubes containing 0.5 M HCl (Lovley \& Phillips 1987). Extraction was terminated by 5 min centrifugation at $3000 \mathrm{rpm}(1811 \mathrm{~g})$ followed by GF/C filtration of the extract. RFE(II) was analysed by the ferrozine method on untreated extract (Stookey 1970). Total reactive $\mathrm{Fe}$ (TRFe) was determined on untreated extract by the ferrozine method after reduction with hydroxylamine. RFe(III) was estimated as the difference between TRFe and RFe(II). The amount of Fe bound in pyrite (PyriteFe) was calculated as described in 'Sample preservation, storage and analysis' below, and total Fe (TFe) in the sediment calculated as $\mathrm{RFe}(\mathrm{II})+\mathrm{RFe}(\mathrm{III})+$ PyriteFe (Valdemarsen et al. 2010).

\section{AVS and CRS}

AVS and CRS were determined on 3 sediment cores from every location in March and September 2010. Individual sediment slices (as described in 'Core slicing' above) were transferred to pre-weighed centrifuge tubes containing $10 \mathrm{ml}$ of $0.5 \mathrm{M}$ zinc acetate $(\mathrm{ZnAc})$ and were frozen $\left(-20^{\circ} \mathrm{C}\right)$. AVS and CRS were determined by the 2-step distillation procedure described in Fossing \& Jørgensen (1989). Distillations were carried out in an anoxic $\left(\mathrm{N}_{2}\right)$ atmosphere, and released AVS and CRS were trapped in separate traps containing $250 \mathrm{mM}$ ZnAc. Pools of AVS and CRS were determined by analysing $\mathrm{TH}_{2} \mathrm{~S}$ in the distillate by the method of Cline (1969).

\section{Microbial reaction rates (jar experiments)}

During every core slicing, microbial reaction rates in sediment at $0-2,2-4,4-6,6-8$ and $8-10 \mathrm{~cm}$ depth were determined from a series of closed anoxic sediment incubations following the methodology of Valdemarsen \& Kristensen (2005). Eight to 10 jars were prepared from each depth interval and buried in anoxic sediment at $8^{\circ} \mathrm{C}$. Pore water was extracted (see 'Core slicing' above) from 2 jars every 3 to $6 \mathrm{~d}$, until no more jars remained. Pore water was sampled for $\mathrm{TCO}_{2}, \mathrm{NH}_{4}{ }^{+}$, and $\mathrm{SO}_{4}{ }^{2-}$ as described in 'Sample preservation, storage and analysis' below. Microbial reaction rates $\left(\mathrm{nmol} \mathrm{cm} \mathrm{cm}^{-3} \mathrm{~d}^{-1}\right)$ were calculated from the slope of the linear regression of solute accumula- tion $\left(\mathrm{TCO}_{2}\right.$ and $\left.\mathrm{NH}_{4}{ }^{+}\right)$or depletion $\left(\mathrm{SO}_{4}{ }^{2-}\right)$ plotted against time and corrected for sediment porosity (Kristensen \& Hansen 1995).

\section{Species richness, abundance, diversity and biomass of benthic infauna}

The remaining 3 sediment cores (only 2 at the reference location in March 2010 and reference and farming locations in February 2011) from each location and sampling occasion were carefully sieved through $5 \mathrm{~mm}$ and $1 \mathrm{~mm}$ mesh screens. Collected fauna was preserved in $4 \%$ buffered formalin for $12 \mathrm{~d}$ and transferred to $70 \%$ ethanol for storage. Infauna ( $>1 \mathrm{~mm}$ ) was identified to the lowest possible taxonomic level (most often to species level), counted and weighed. Total dry weight was calculated for the whole fauna assemblage from each core drying at $80^{\circ} \mathrm{C}$ for $36 \mathrm{~h}$, and ash-free dry weight was calculated after combustion for $6 \mathrm{~h}$ at $520^{\circ} \mathrm{C}$ (Kutti et al. 2007b).

\section{Sample preservation, storage and analysis}

$\mathrm{TCO}_{2}$ samples were preserved with $\mathrm{HgCl}_{2}$ (volume ratio 9:1), stored cool $\left(5^{\circ} \mathrm{C}\right)$ and analysed by flow injection analysis (Hall \& Aller 1992) within $14 \mathrm{~d}$ of sample collection. Samples for $\mathrm{SO}_{4}{ }^{2-}, \mathrm{Br}^{-}$, and $\mathrm{NH}_{4}{ }^{+}$ were stored frozen $\left(-20^{\circ} \mathrm{C}\right)$ until analysis. $\mathrm{NH}_{4}{ }^{+}$was analysed by colorimetric analysis as described in Kerouel \& Aminot (1997). $\mathrm{SO}_{4}{ }^{2-}$ and $\mathrm{Br}^{-}$were analysed by liquid ion chromatography on a Dionex ICS2000 system. Samples for $\mathrm{TH}_{2} \mathrm{~S}$ were preserved with 1.0 M ZnAc and analysed according to Cline (1969). Samples for pore water $\mathrm{Fe}^{2+}$ were preserved with $0.5 \mathrm{M} \mathrm{HCl}$ (sample: $\mathrm{HCl}$ volume ratio of 1:1) and stored at room temperature. Pore water $\mathrm{Fe}^{2+}$ was analysed by the ferrozine method (Stookey 1970). To calculate the amount of Fe used for sulphide precipitation during the experiment (pyriteFe), it was assumed that all CRS was pyrite and that all AVS was FeS (Canfield 1989).

\section{Statistical analysis}

Statistical analysis was carried out using the SYSTAT statistical package within SIGMAPLOT 11.2. Data analysed using repeated-measures ANOVA were checked for homogeneity of variances and normality using standardised residuals versus predicted value plots and $\mathrm{Q}-\mathrm{Q}$ plots of residuals. Flux data 
$\left(\mathrm{O}_{2}, \mathrm{TCO}_{2}, \mathrm{NH}_{4}^{+}\right)$and infauna data (biomass and abundance) were analysed separately by way of 2-factor repeated-measures ANOVAs (factors: [1] Location and [2] Month). All data were transformed using log $(x+1)$ to meet the assumptions (Underwood 1981). Statistical differences were interpreted using Tukey's honestly significant difference (HSD) multiple comparisons test (Quinn \& Keough 2002). Infauna community composition were analysed using the Primer software package. Log $(x+1)$-transformed data were analysed using a 1-way analysis of similarity (ANOSIM) test based on Bray-Curtis similarity matrices to identify differences in species richness between reference and farming locations over the production cycle (Clarke 1993) and all data were visually represented using multidimensional scaling (MDS) ordinations. Species contributions to infauna richness were determined using the 1-way similarity percentages (SIMPER) analysis based on Bray-Curtis similarity matrices (Clarke 1993). Microbial reaction rates from jar experiments were obtained by regression analysis of metabolite concentration plotted versus time. The volume-specific reaction rates were calculated based on the slopes of linear regressions and were only reported when the slopes of linear regressions were significantly different from zero (Quinn \& Keough 2002). The measure of variation associated with the reporting of all mean values is 1 standard error (SE) unless stated otherwise.

\section{RESULTS}

\section{Hydrodynamics}

The current velocities at the sampling locations varied during the production cycle and fallowing period (Table 2). Current velocities were similar at both locations, but the range of current velocities was slightly lower at the reference location $(<2.0$ to $31.4 \mathrm{~cm} \mathrm{~s}^{-1}$ and $<2.0$ to $44.8 \mathrm{~cm} \mathrm{~s}^{-1}$ at the farming and reference locations, respectively). The direction of the current remained similar during the sampling occasions, with the current direction at the farming location predominantly heading east, while at the reference location it shifted southerly. The proportion of current velocities exceeding $10 \mathrm{~cm} \mathrm{~s}^{-1}$ at the farming location were on average $7.8 \pm 2.7 \%$ (Mar), $15.3 \pm 3.3 \%$ (Jun), $5.7 \pm 1.6 \%$ (Sep) and $16.1 \pm 4.2 \%$ (Feb) of the daily measurement time, respectively.
The proportion of current velocities exceeding $10 \mathrm{~cm}$ $\mathrm{s}^{-1}$ at the reference location were $5.5 \pm 2.9 \%$ (Mar), $14.3 \pm 2.6 \%$ (Sep) and $9.4 \pm 3.5 \%$ (Feb) of the daily measurement time, respectively.

\section{Sedimentation}

TPM sedimentation rates differed between sampling locations and were highest at the farming location on all sampling occasions (generally 14 to $60 \%$ higher; Table 3). The organic content (POC and TN) of settled material followed this pattern and was up to $55 \%$ higher at the farming location in March and September (Table 3). Additionally, at both locations, TPM and POC sedimentation were higher at the bottom compared to $80 \mathrm{~m}$ above the bottom during March, September and February (36 to $77 \%$ higher; Table 3), indicating that resuspension occurred at both locations.

\section{Sediment properties}

At the farming location, the surface sediment consisted of coarse to medium sand, with a median grain size of $542 \mu \mathrm{m}$. The sediments became finer grained with increasing sediment depth (Table 4). The sediment structure at the reference location was markedly different from the farming location (Table 4). The surface sediment was silt-mud with a median grain size of $62 \mu \mathrm{m}$. Subsurface sediments were coarser and had a median grain size ranging between 67 and $98 \mu \mathrm{m}$ (Table 4). At both locations, sediment density was consistent, with values ranging between 1.4 and $1.8 \mathrm{~g} \mathrm{ml}^{-1}$ down to $10 \mathrm{~cm}$ depth (Table 4). 
POC and TN content of bottom sediments were on average 2 times higher at the farming location than at the reference location (Table 4). Eleven months into the production cycle, sediment POC at the farming location was higher at the surface $(6.5 \%)$ than deeper in the sediment (5.3\% at $10 \mathrm{~cm}$ depth). By the end of the production cycle, however, the depth concentration of POC shifted, and the lowest POC was found in surface sediments $(3.5 \%)$ when compared to the deeper sediment $(6.9 \%)$. TN concentrations at the farming location were stable to $10 \mathrm{~cm}$ depth over the production cycle, with slightly elevated TN concentrations in the upper $2 \mathrm{~cm}$. With the exception of the top $2 \mathrm{~cm}$, POC and TN content of sediments decreased during the fallowing period. The $\mathrm{C}: \mathrm{N}$ ratios of organic matter in the sediments at the farming location ranged from 16 to 69. At the reference location, the POC and TN content of bottom sediments remained stable irrespective of sampling time and sediment depth. POC and TN ranged between 2.5 and
$3.2 \%$ and 0.1 and $0.2 \%$, respectively, and $\mathrm{C}: \mathrm{N}$ ratios were 15 to 32 throughout the study period.

\section{Faunal abundance, biomass, diversity and community composition}

A total of 113 taxa were identified from the 21 sediment cores collected at the farming and reference locations in this study. The abundance of infauna increased over the production cycle by 4.5 and 2.0 times at the farming and reference locations, respectively (Table 5). Although the significant interaction term of Month $\times$ Location (2-factor repeatedmeasures ANOVA: $F_{3,9}=6.910, \mathrm{p}=0.01$ ) limits our interpretation of the main effects, infauna abundance was 2.5 to 6.5 times higher at the farming location than at the reference location over the production cycle (Table 5). During the fallowing period, the abundance of infauna decreased at both the farming

Table 3. Sedimentation rates of total particulate matter (TPM; $\mathrm{g} \mathrm{m}^{-2} \mathrm{~d}^{-1}$ ), particulate organic carbon $\left(\mathrm{POC}_{i} \mathrm{mmol} \mathrm{C} \mathrm{m}^{-2} \mathrm{~d}^{-1}\right)$ and total nitrogen $\left(\mathrm{TN}_{\text {; }} \mathrm{mmol} \mathrm{N} \mathrm{m} \mathrm{N}^{-2} \mathrm{~d}^{-1}\right.$ ) at the farming and reference locations in March, July and September 2010 and February 2011. Numbers in parentheses show SD $(n=2)$. na: data not available

\begin{tabular}{|c|c|c|c|c|c|c|c|}
\hline \multirow{2}{*}{ Month } & \multirow{2}{*}{$\begin{array}{c}\text { Distance above } \\
\text { bottom (m) }\end{array}$} & \multicolumn{3}{|c|}{ - Farm } & \multicolumn{3}{|c|}{-Reference } \\
\hline & & TPM & POC & $\mathrm{TN}$ & TPM & POC & $\mathrm{TN}$ \\
\hline \multirow{2}{*}{ Mar } & 10 & $7.2(0.1)$ & $45.1(11.2)$ & $4.0(1.2)$ & $6.1(0.4)$ & $32.1(2.7)$ & $3.2(0.03)$ \\
\hline & 80 & $3.8(0.6)$ & $23.1(0.2)$ & $2.9(0.1)$ & $2.5(0.01)$ & $20.3(2.4)$ & $3.6(0.2)$ \\
\hline \multirow[t]{2}{*}{ Jul } & 10 & 16.2 & 166.4 & 15.2 & na & na & na \\
\hline & 80 & 10.35 & 235.9 & 16.4 & na & na & na \\
\hline \multirow[t]{2}{*}{ Sep } & 10 & $26.2(11.4)$ & $112.0(9.0)$ & $10.8(7.3)$ & $10.5(0.2)$ & $72.4(16.2)$ & $11.8(2.4)$ \\
\hline & 80 & $6.1(1.3)$ & $71.5(7.1)$ & $9.6(0.7)$ & $3.6(0.01)$ & $39.4(5.6)$ & $5.3(0.7)$ \\
\hline \multirow[t]{2}{*}{ Feb } & 10 & $11.7(1.5)$ & $65.1(8.1)$ & $17.5(2.0)$ & $9.8(0.4)$ & $48.7(5.9)$ & 15.1 \\
\hline & 80 & $4.2(0.1)$ & 36.5 (4.9) & 13.4 (1.5) & $2.3(0.3)$ & $12.8(0.7)$ & $7.4(0.5)$ \\
\hline
\end{tabular}

Table 4. Sediment characteristics at the farming and reference locations in 2010 and 2011. POC: particulate organic carbon, TN: total nitrogen

\begin{tabular}{|c|c|c|c|c|c|c|c|c|c|c|c|c|c|c|}
\hline \multirow[t]{2}{*}{ Location } & \multirow{2}{*}{$\begin{array}{l}\text { Depth } \\
\text { (cm) }\end{array}$} & \multirow{2}{*}{$\begin{array}{l}\text { Median grain } \\
\text { size }(\mathrm{mm})\end{array}$} & \multicolumn{3}{|c|}{ Mar 2010} & \multicolumn{3}{|c|}{ Jun 2010} & \multicolumn{3}{|c|}{- Sep 2010} & \multicolumn{3}{|c|}{ - Feb 2011 } \\
\hline & & & $\begin{array}{c}\text { POC } \\
(\%)\end{array}$ & $\begin{array}{l}\mathrm{TN} \\
(\%)\end{array}$ & $\begin{array}{l}\text { Density } \\
\left(\mathrm{g} \mathrm{ml}^{-1}\right)\end{array}$ & $\begin{array}{c}\text { POC } \\
(\%)\end{array}$ & $\begin{array}{l}\mathrm{TN} \\
(\%)\end{array}$ & $\begin{array}{l}\text { Density } \\
\left(\mathrm{g} \mathrm{ml}^{-1}\right)\end{array}$ & $\begin{array}{c}\text { POC } \\
(\%)\end{array}$ & $\begin{array}{l}\text { TN } \\
(\%)\end{array}$ & $\begin{array}{l}\text { Density } \\
\left(\mathrm{g} \mathrm{ml}^{-1}\right)\end{array}$ & $\begin{array}{c}\text { POC } \\
(\%)\end{array}$ & $\begin{array}{l}\text { TN } \\
(\%)\end{array}$ & $\begin{array}{l}\text { Density } \\
\left(\mathrm{g} \mathrm{ml}^{-1}\right)\end{array}$ \\
\hline \multirow[t]{5}{*}{ Farm } & $0-2$ & 547 & 6.46 & 0.38 & 1.49 & 6.18 & 0.22 & 1.40 & 3.47 & 0.16 & 1.43 & 6.09 & 0.22 & 1.44 \\
\hline & $2-4$ & 167 & 6.19 & 0.21 & 1.45 & 6.19 & 0.20 & 1.55 & 5.87 & 0.19 & 1.52 & 6.03 & 0.18 & 1.50 \\
\hline & $4-6$ & 166 & 5.84 & 0.18 & 1.50 & 6.10 & 0.19 & 1.60 & 5.25 & 0.18 & 1.58 & 5.32 & 0.18 & 1.56 \\
\hline & $6-8$ & 116 & 5.35 & 0.16 & 1.48 & 6.86 & 0.15 & 1.57 & 6.36 & 0.16 & 1.49 & 5.29 & 0.15 & 1.54 \\
\hline & $8-10$ & 82 & 5.25 & 0.16 & 1.52 & 5.12 & 0.15 & 1.60 & 6.87 & 0.15 & 1.63 & 5.99 & 0.15 & 1.58 \\
\hline \multirow[t]{5}{*}{ Reference } & $0-2$ & 62 & 2.87 & 0.14 & 1.51 & 2.94 & 0.16 & 1.47 & 3.18 & 0.15 & 1.49 & 2.70 & 0.14 & 1.51 \\
\hline & $2-4$ & 67 & 2.64 & 0.14 & 1.60 & 3.13 & 0.17 & 1.56 & 3.01 & 0.15 & 1.79 & 2.71 & 0.15 & 1.87 \\
\hline & $4-6$ & 89 & 2.65 & 0.15 & 1.68 & 2.93 & 0.14 & 1.61 & 3.34 & 0.15 & 1.66 & 3.19 & 0.14 & 1.60 \\
\hline & $6-8$ & 98 & 2.50 & 0.13 & 1.67 & 2.67 & 0.13 & 1.58 & 3.17 & 0.14 & 1.69 & 2.94 & 0.13 & 1.65 \\
\hline & $8-10$ & 93 & 2.68 & 0.13 & 1.71 & 2.53 & 0.12 & 1.57 & 3.00 & 0.14 & 1.71 & 2.81 & 0.13 & 1.65 \\
\hline
\end{tabular}


Table 5. Summary of the abundance (ind. $\left.\mathrm{m}^{-2}\right)$, biomass $\left(\mathrm{g} \mathrm{m}^{-2}\right)$, species richness and diversity (Shannon-Wiener index) of infauna observed in sediment cores collected at farming and reference locations over the production cycle from March 2010 to February 2011. Mean abundances of individual fauna in the sub-cores for each month are presented (abundance/core). Numbers in parentheses indicate SE

\begin{tabular}{|llcccc|}
\hline & \multirow{2}{*}{ Station } & \multicolumn{4}{c|}{ Month sampled } \\
\cline { 3 - 5 } & & Mar & Jun & Sep & Feb \\
\hline \multirow{2}{*}{ Abundance } & Farm & $19278(3281)$ & $23906(1952)$ & $85732(6016)$ & $50318(19618)$ \\
& Reference & $6306(2102)$ & $7134(367)$ & $13121(808)$ & $5796(64)$ \\
Biomass & Farm & $36.7(3.7)$ & $36.5(3.9)$ & $57.3(4.5)$ & $37.8(4.3)$ \\
& Reference & $5.8(0.3)$ & $12.3(1.7)$ & $16.0(4.2)$ & $5.7(0.4)$ \\
Species & Farm & $30(4)$ & $29(1)$ & $30(3)$ & $26(3)$ \\
richness & Reference & $20(1)$ & $26(2)$ & $37(3)$ & $24(0)$ \\
Diversity & Farm & $2.5(0.2)$ & $2.5(0.1)$ & $1.7(0.10)$ & $1.9(0.5)$ \\
& Reference & $2.6(0.2)$ & $2.7(0.1)$ & $3.2(0.2)$ & $2.9(0.02)$ \\
Abundance/ & Farm & $151(26)$ & $187(15)$ & $673(47)$ & $395(154)$ \\
core & Reference & $50(7)$ & $56(3)$ & $103(6)$ & $46(1)$ \\
\hline
\end{tabular}

Sep: $\mathrm{R}=0.2 ;$ Mar to Sep: $\mathrm{R}=$ 0.9; Mar to Feb: $\mathrm{R}=0$ ).

SIMPER analysis showed that the dissimilarity of the infauna composition within the farming $(44 \%$ at the end of production) and reference (60\% at the end of production) locations remained stable over the production cycle of the farm. Capitellid polychaetes (Capitella capitata and Heteromastus filformis), other polychates (Aphelochaeta spp. and Chaetozone spp.) and small bivalves (Abra nitida and Kurtiella bidentata) accounted for a large proportion (66 to $89 \%$ ) of the infauna

and reference location; however, the abundance of infauna at the farming location remained higher than at the reference location.

Infauna biomass at the farming and reference location increased significantly over the production cycle (2-factor repeated-measures ANOVA: $F_{3,9}=11.448, \mathrm{p}$ $=0.002$ ) by 1.6 and 2.8 times, respectively. Furthermore, infauna biomass was significantly higher at the farming location compared to the reference location (2.8 to 6.1 times) over the production cycle (2factor repeated-measures ANOVA: $F_{1,9}=94.197, \mathrm{p}<$ 0.01 ; Table 5). During the fallowing period, the biomass of infauna at both reference and farming locations decreased; however, the biomass of infauna at the farming location remained higher than at the reference location.

Species diversity (measured as the Shannon-Wiener diversity index) and richness varied between the sampled locations and over the production cycle of the fish farm. Species richness in individual cores ranged from 19 (farming location in March) to 42 individual species (reference location in September). Species diversity was lower at the farming location when compared to the reference location (Table 5), and varied over the production cycle. Based on the abundance and composition of faunal communities in individual cores, MDS techniques provided separation between farming and reference locations on all sampling dates (ANOSIM: global $\mathrm{R}=0.6, \mathrm{p}=0.01$; Fig. 2). Furthermore, species abundance and composition varied over the production and recovery periods at both the farming (ANOSIM: Mar to Jun: $\mathrm{R}=0$; Jun to Sep: $\mathrm{R}=$ 0.1; Mar to Sep: $\mathrm{R}=0.6$; Mar to Feb: $\mathrm{R}=0.1$ ) and reference locations (ANOSIM: Mar to Jun: $\mathrm{R}=0.4$; Jun to abundance at the farming location (Table 6). The polychaetes Myriochele oculata and Paramphinome jeffreysii and the echinoderm Amphiura filiformis were common at both locations, whilst a few species of polychaetes (Spiophanes kroeyeri) and bivalves (Mendicula ferruginosa, Parvicardium minimum and Kelliella abyssicola) were found exclusively at the reference location (Table 6).

\section{Solute exchange between sediment and overlying water}

Sediment oxygen uptake at the reference location was relatively stable, 9 to $20 \mathrm{mmol} \mathrm{m}^{-2} \mathrm{~d}^{-1}$, during the

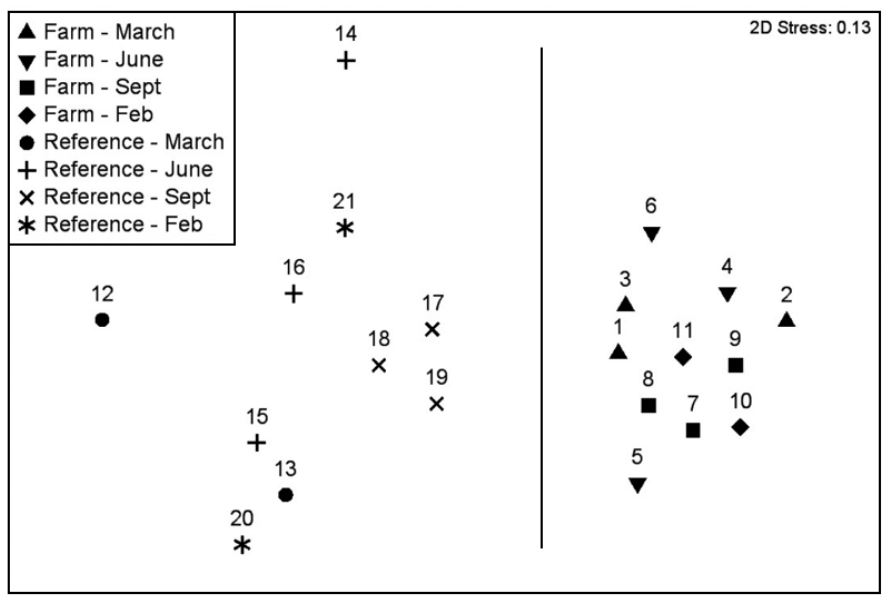

Fig. 2. Multidimensional scaling plot of infauna community composition at the farming and reference locations at different times in the production cycle (March, June and September 2010) and fallowing period (February 2011) 
different sampling occasions (Fig. 3a), with a significantly higher oxygen uptake rate in September 2010 (Tukey's HSD, p < 0.01). At the farming location, $\mathrm{O}_{2}$ uptake was 4 to 6 times higher than at the reference location (2factor repeated-measures ANOVA: $F_{1,9}=154.2, \mathrm{p}<$ 0.001 ) and showed an increasing trend over the production cycle, from $65.8 \pm 6.2 \mathrm{mmol} \mathrm{m}^{-2} \mathrm{~d}^{-1}$ in March, to $67.4 \pm 10.0$ and $102.2 \pm 11.1 \mathrm{mmol} \mathrm{m}^{-2} \mathrm{~d}^{-1}$ in June and September, respectively (Fig. 3a). In addition, oxygen flux decreased at both farming and reference locations during the fallowing period to $40.6 \pm 7.4$ and $10.7 \pm 1.9 \mathrm{mmol} \mathrm{m}^{-2} \mathrm{~d}^{-1}$, respectively. $\mathrm{TCO}_{2}$ effluxes mirrored the $\mathrm{O}_{2}$ uptake and were significantly lower at the reference location (6 to $19 \mathrm{mmol} \mathrm{m}^{-2} \mathrm{~d}^{-1}$ ) when compared to the farm site (56 to $63 \mathrm{mmol} \mathrm{m}^{-2} \mathrm{~d}^{-1}$ ) (2-factor repeated-measures ANOVA: $F_{1,9}=79.013$, $\mathrm{p}<0.001$ ) (Fig. 3b) and were not significantly different over the sampling occasions (2-factor repeatedmeasures ANOVA: $F_{3,23}=0.977, \mathrm{p}=0.421$ ) (Fig. 3b).

$\mathrm{NH}_{4}{ }^{+}$release was significantly higher at the farming site ( 6 to $21 \mathrm{mmol} \mathrm{m}^{-2} \mathrm{~d}^{-1}$ ) compared to the reference location ( 0.3 to $1.5 \mathrm{mmol} \mathrm{m}^{-2} \mathrm{~d}^{-1}$ ) over the different sampling occasions (2-factor repeated-measures
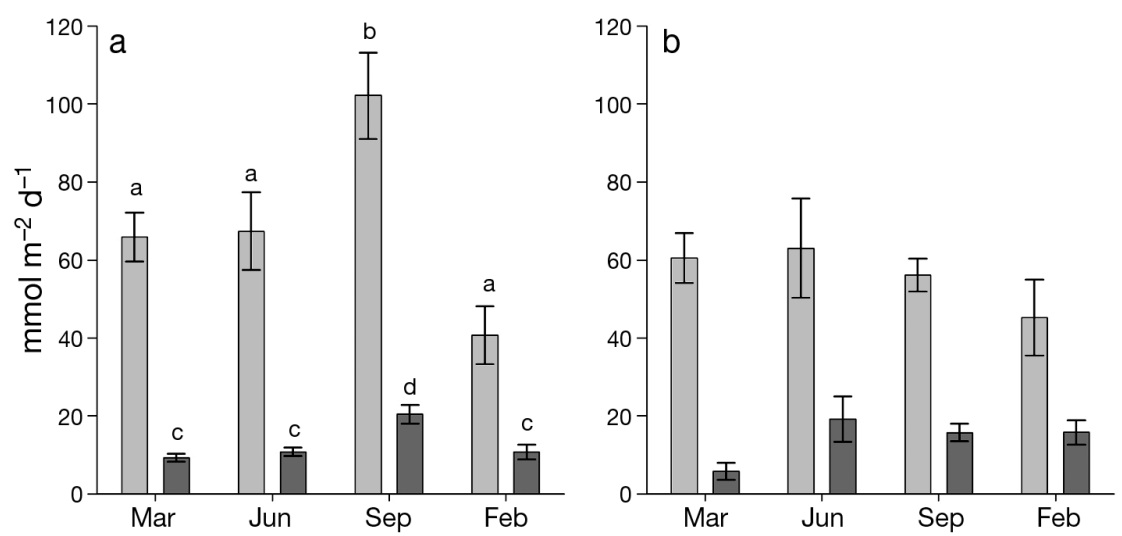

Fig. 3. Average (a) sediment oxygen consumption, and effluxes of (b) total $\mathrm{CO}_{2}$ and (c) $\mathrm{NH}_{4}{ }^{+}$at the farming and reference location at 3 different time points over the production cycle. Superscripts denote significant differences across seasons and between sampling locations as defined by Tukeys HSD post hoc test at $\mathrm{p}<0.01$. Error bars represent SE ( $\mathrm{n}=6$ ). Note the different $y$-axis scales

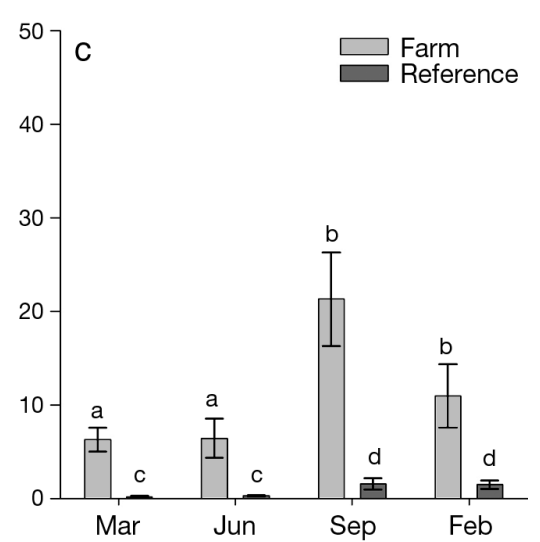

ANOVA: $\left.F_{1,9}=34.8, \mathrm{p}<0.001\right)$, including the fallowing period. On average, $\mathrm{NH}_{4}{ }^{+}$release was stimulated 2 to 20 times at the farm site compared to the reference location (Fig. 3c). The ratio between $\mathrm{TCO}_{2}$ efflux and $\mathrm{NH}_{4}{ }^{+}$efflux $\left(\mathrm{TCO}_{2}: \mathrm{NH}_{4}{ }^{+}\right)$decreased over the production cycle at the farming (from 9.6 in March 2010 to 2.6 in September 2010) and reference locations (from 35.2 in March 2010 to 10.2 in September 2010). During the fallowing period, $\mathrm{TCO}_{2}: \mathrm{NH}_{4}{ }^{+}$ increased at the farming location (4.1) and remained stable at the reference location (10.7).
Table 6. Mean abundance (ind. $\mathrm{m}^{-2}$ ) of the 5 most dominant species recorded from replicate
sediment cores from March 2010 to February 2011 at both sampling locations. Note that the mean abundance for 3 replicate sediment cores re-calculated to ind. $\mathrm{m}^{-2}$ if not indicated otherwise

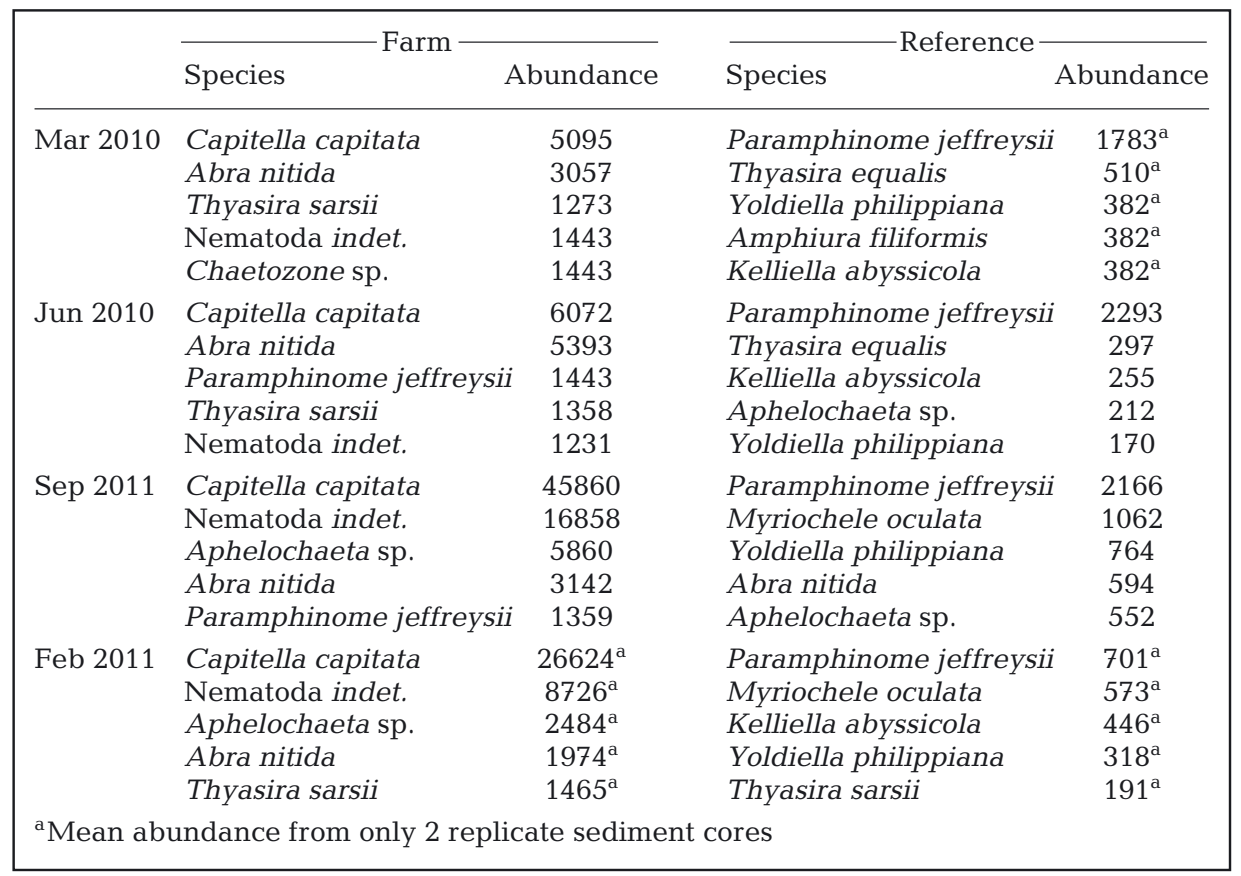




\section{Pore-water solutes}

The pore water concentration of $\mathrm{TCO}_{2}$ and $\mathrm{SO}_{4}{ }^{2-}$ was constant regardless of location, sediment depth and sampling time (Fig. $4 \mathrm{a}-\mathrm{d}$ ). $\mathrm{NH}_{4}{ }^{+}$, on the other hand, accumulated at increasing sediment depth on both locations, and increased from 23-79 $\mu \mathrm{M}$ at $0.5 \mathrm{~cm}$ depth to $88-382 \mu \mathrm{M}$ at $9 \mathrm{~cm}$ depth (Fig. $4 \mathrm{e}, \mathrm{f}$ ). $\mathrm{TH}_{2} \mathrm{~S}$ in pore water was consistently low and ranged between 0-6 and 0-30 $\mu \mathrm{M}$ at the reference and farming locations, respectively (Fig. $4 \mathrm{~g}, \mathrm{~h}$ ). $\mathrm{Fe}^{2+}$ showed an overall increase from March to September 2010 on both locations, from an average of $25 \pm 3$ to $51 \pm 5 \mu \mathrm{M}$ at the reference location and from $9 \pm 1$ to $43 \pm 5 \mu \mathrm{M}$ at the farming location. Furthermore, a subsurface $\mathrm{Fe}^{2+}$ peak, which was absent in March, was evident at $1.5 \mathrm{~cm}$ depth on both locations in September (peak was $76 \pm 22$ and $67 \pm 23 \mu \mathrm{M}$ at the reference and farming locations, respectively) (data not shown).

\section{Solid-phase iron and sulphur}

There were only few differences between the reference and farming locations with respect to the concentration and speciation of solid-phase Fe. At the reference location in March, RFe(II) increased from $3.7 \pm 1.8 \mu \mathrm{mol} \mathrm{cm} \mathrm{cm}^{-3}$ at $0.5 \mathrm{~cm}$ depth to an average of $31.2 \pm 1.3 \mu \mathrm{mol} \mathrm{cm}{ }^{-3}$ below $2 \mathrm{~cm}$ depth. RFe(III), on the other hand, was highest $\left(16.3 \pm 2.1 \mu \mathrm{mol} \mathrm{cm}{ }^{-3}\right)$ in surface sediment ( 0 to $2 \mathrm{~cm}$ depth) and was depleted to $<1 \mu \mathrm{mol} \mathrm{cm} \mathrm{cm}^{-3}$ below $5 \mathrm{~cm}$ depth. At the farm location, the distribution of RFe(II) was relatively con-

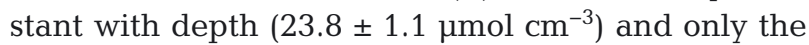
upper $2 \mathrm{~cm}$ of sediment was enriched with RFe(III) $\left(1.8 \pm 0.5 \mu \mathrm{mol} \mathrm{cm}{ }^{-3}\right.$ compared to $1.1 \pm 0.2 \mu \mathrm{mol} \mathrm{cm}{ }^{-3}$ below). A similar distribution of the different $\mathrm{Fe}$ forms was observed in September.

The area-specific TFe pools were higher at the reference location than at the farm in March (3.2 \pm 0.1 vs. $2.7 \pm 0.1 \mathrm{~mol} \mathrm{~m}^{-2}$, respectively; Fig. 5a). The Fe was primarily composed of reduced Fe forms (3-7 and 84-89\% was PyriteFe or $\mathrm{RFe}(\mathrm{II})$, respectively) and only 4 to $15 \%$ of TFe was RFe(III). In September, the Fe speciation was similar $(4-5,85-91$ and $5-10 \%$ of TFe was PyriteFe, RFe(II) and RFe(III), respectively), but the TFe pools were 27 to $29 \%$ lower (Fig. 5a).

In March, sediment AVS content increased from $<0.1 \mu \mathrm{mol} \mathrm{cm}{ }^{-3}$ at $0.5 \mathrm{~cm}$ depth to $2.4 \pm 0.1 \mu \mathrm{mol} \mathrm{cm}{ }^{-3}$ at $9 \mathrm{~cm}$ depth at the reference location, whereas CRS content was relatively constant $(\sim 1.7 \pm 0.1 \mu \mathrm{mol}$ $\mathrm{cm}^{-3}$ ). At the farming location, AVS was similar to the reference location (on average, $2.4 \pm 0.3 \mu \mathrm{mol} \mathrm{cm}{ }^{-3}$ ), whereas CRS content was higher (on average, $3.7 \pm$ $0.2 \mu \mathrm{mol} \mathrm{cm}{ }^{-3}$ ). In March, area-specific total reduced inorganic sulphide (TRIS) content was $\sim 1.8$ times higher at the farming location than at the reference location (Fig. 5b). In September, the AVS was evenly distributed with depth at both locations and was on average $0.8 \pm 0.1$ (reference) and $0.5 \pm 0.1$ (farming) $\mu \mathrm{mol} \mathrm{cm}^{-3}$. The same stable depth distribution was observed for CRS (on average $2.5 \pm 0.2$ and $1.4 \pm$ $0.2 \mu \mathrm{mol} \mathrm{cm} \mathrm{cm}^{-3}$ at the reference and farming location, respectively). Thus in September, the area-specific TRIS content was 1.6 times higher at the reference location when compared to the farming location (Fig. 5b). Over the whole study, there was no change in area-specific TRIS at the reference location, whereas at the farming location, TRIS decreased by $68 \%$ between March and September.

\section{Jar experiments}

$\mathrm{TCO}_{2}$ production was relatively constant over the production cycle at the farming location and decreased during the fallowing period (Fig. 6). $\mathrm{TCO}_{2}$ production was always highest at the sediment

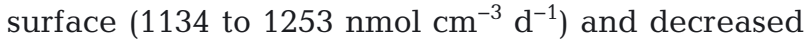
gradually with depth to on average $313 \mathrm{nmol} \mathrm{cm}^{-3} \mathrm{~d}^{-1}$ below $6 \mathrm{~cm}$ depth. At the reference location, the vertical distribution of $\mathrm{TCO}_{2}$ production was similar in March and June 2010. $\mathrm{TCO}_{2}$ production showed a subsurface peak at 2 to $6 \mathrm{~cm}$ depth (260 to $390 \mathrm{nmol}$ $\mathrm{cm}^{-3} \mathrm{~d}^{-1}$ ) and was lower at the sediment surface (154 to $181 \mathrm{nmol} \mathrm{cm}^{-3} \mathrm{~d}^{-1}$ ) and below $6 \mathrm{~cm}$ depth (80 to $228 \mathrm{nmol} \mathrm{cm}^{-3} \mathrm{~d}^{-1}$ ). However, during September, the production rates of $\mathrm{TCO}_{2}$ apparently increased at the reference location, to levels that were similar to the farming location (Fig. 6). Depth-integrated $\mathrm{TCO}_{2}$ production based on jar experiments decreased slightly during the production cycle at the farming location $\left(65.8 \pm 4.5 \mathrm{mmol} \mathrm{m} \mathrm{m}^{-2} \mathrm{~d}^{-1}\right.$ in March to $53.6 \pm$ $5.2 \mathrm{mmol} \mathrm{m}^{-2} \mathrm{~d}^{-1}$ in September), but increased at the reference location $\left(21.8 \pm 3.5 \mathrm{mmol} \mathrm{m}^{-2} \mathrm{~d}^{-1}\right.$ in March to $56.2 \pm 5.1 \mathrm{mmol} \mathrm{m}^{-2} \mathrm{~d}^{-1}$ in September). During the fallowing period, depth-integrated $\mathrm{TCO}_{2}$ production decreased at the farming and reference locations $\left(43.6 \pm 3.2\right.$ and $38.3 \pm 3.4 \mathrm{mmol} \mathrm{m}^{-2} \mathrm{~d}^{-1}$, respectively)

The rates of $\mathrm{SO}_{4}{ }^{2-}$ consumption in jar experiments followed a similar pattern as $\mathrm{TCO}_{2}$ production (Fig. 6). At the farming site, $\mathrm{SO}_{4}{ }^{2-}$ consumption was highest in the upper $2 \mathrm{~cm}$ (374 to $476 \mathrm{nmol} \mathrm{cm}^{-3} \mathrm{~d}^{-1}$ ) and decreased with depth to $9 \mathrm{~cm}$ deep (81.3 \pm $18.8 \mathrm{nmol} \mathrm{cm}^{-3} \mathrm{~d}^{-1}$ in June). At the reference location, $\mathrm{SO}_{4}{ }^{2-}$ consumption varied from $0 \mathrm{nmol} \mathrm{cm}{ }^{-3} \mathrm{~d}^{-1}$ 


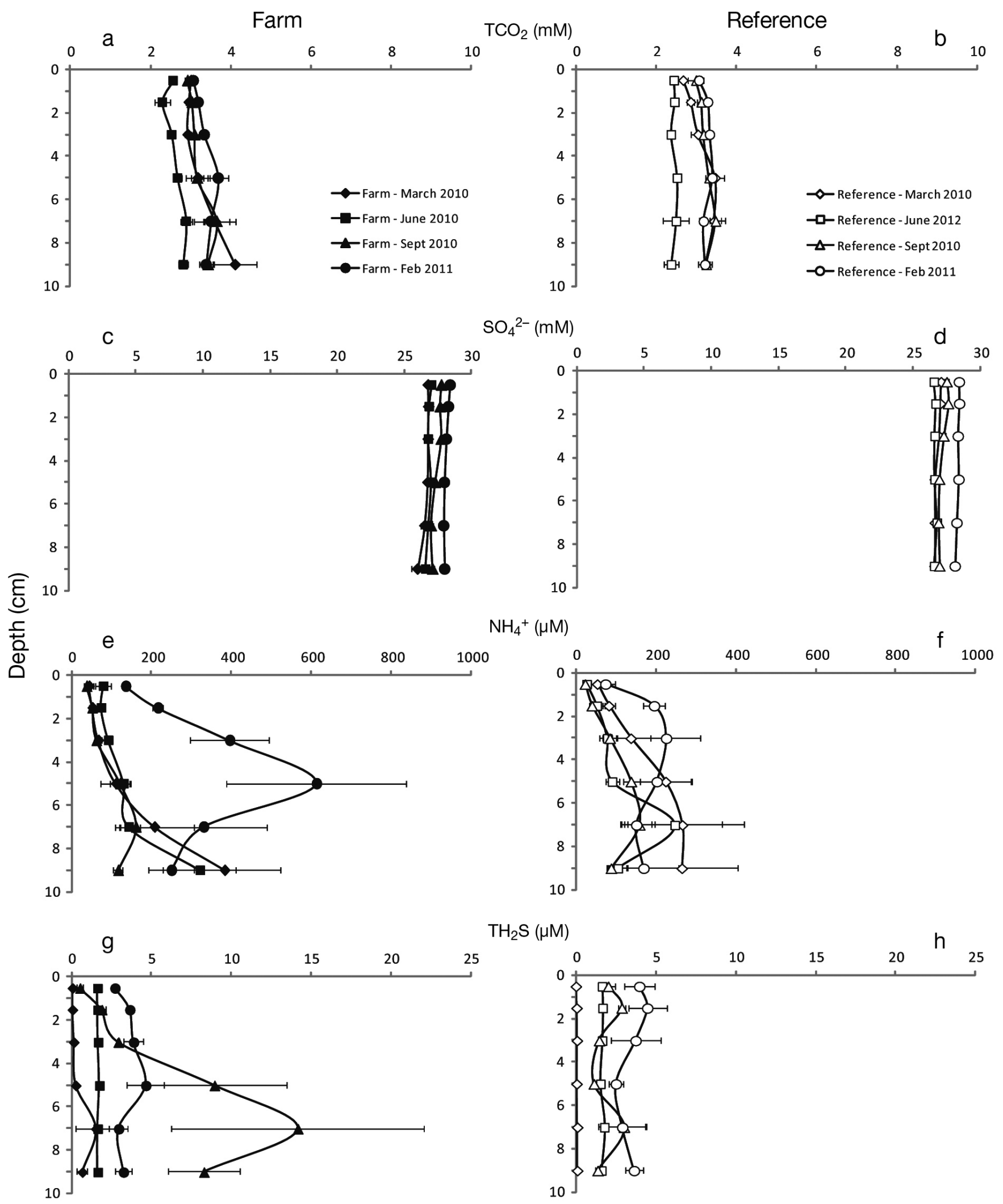

Fig. 4. Average concentration of pore water solutes in sediments from the farming (solid symbols; left column) and reference (open symbols; right column) locations at 3 different time points over the production cycle: $(\mathrm{a}, \mathrm{b})$ total $\mathrm{CO}_{2}\left(\mathrm{TCO}_{2}\right),(\mathrm{c}, \mathrm{d}) \mathrm{SO}_{4}{ }^{2-}$, $(\mathrm{e}, \mathrm{f}) \mathrm{NH}_{4}{ }^{+}$and $(\mathrm{g}, \mathrm{h})$ total $\mathrm{H}_{2} \mathrm{~S}\left(\mathrm{TH}_{2} \mathrm{~S}\right)$. Error bars represent $\mathrm{SE}(\mathrm{n}=3)$ 

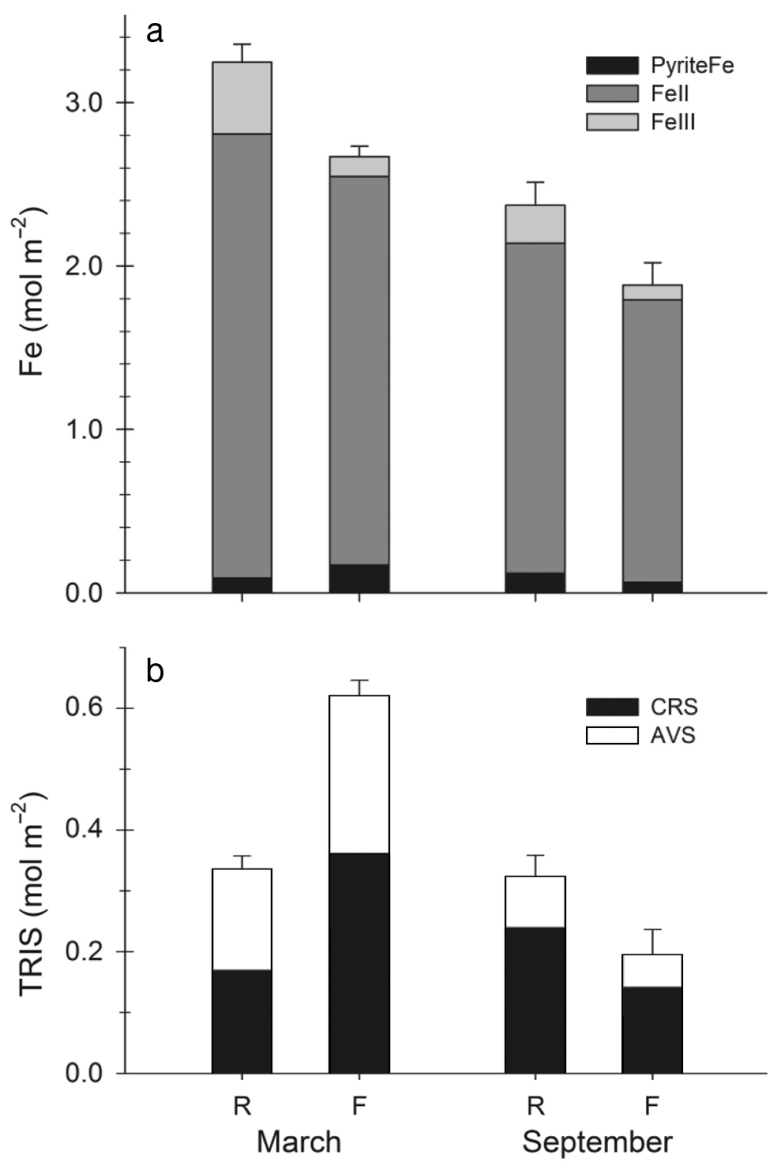

Fig. 5. Depth-integrated (0 to $10 \mathrm{~cm}$ depth), area-specific pools of (a) total Fe and (b) total reduced inorganic sulphides (TRIS) at the reference (R) and farming (F) locations in March and September. The different colours of bars indicate the relative contribution of different Fe- or S-compounds to total Fe and TRIS (AVS: acid volatile sulphides, CRS: chromium reducible sulphides, PyriteFe: Fe bound in pyrite). Error bars represent $\mathrm{SE}(\mathrm{n}=3)$

measured at $9 \mathrm{~cm}$ depth in June to $438.4 \pm 34.4 \mathrm{nmol}$ $\mathrm{cm}^{-3} \mathrm{~d}^{-1}$ measured at $3 \mathrm{~cm}$ depth in September. The average C:S stoichiometry based on $\mathrm{TCO}_{2}$ production and $\mathrm{SO}_{4}{ }^{2-}$ consumption in jars was 2.0 and 1.9 at the farming and reference location, respectively, indicating that microbial sulphate reduction was the main metabolic pathway and that sulphide precipitation with e.g. $\mathrm{Fe}^{2+}$ was negligible (Valdemarsen et al. 2010). Depth-integrated $\mathrm{SO}_{4}{ }^{2-}$ consumption rates decreased at the farming location (from $33.2 \pm 3.8 \mathrm{mmol}$ $\mathrm{m}^{-2} \mathrm{~d}^{-1}$ in March to $26.6 \pm 2.0 \mathrm{mmol} \mathrm{m}^{-2} \mathrm{~d}^{-1}$ in September) and increased at the reference location (from $11.3 \pm 2.6 \mathrm{mmol} \mathrm{m}^{-2} \mathrm{~d}^{-1}$ in March to $29.0 \pm 3.8 \mathrm{mmol}$ $\mathrm{m}^{-2} \mathrm{~d}^{-1}$ in September). During the fallowing period, $\mathrm{SO}_{4}{ }^{2-}$ consumption remained stable at the farming location $\left(28.7 \pm 2.0 \mathrm{mmol} \mathrm{m}^{-2} \mathrm{~d}^{-1}\right)$, but decreased at the reference location $\left(17.1 \pm 2.9 \mathrm{mmol} \mathrm{m}^{-2} \mathrm{~d}^{-1}\right)$.
At the farming location, $\mathrm{NH}_{4}{ }^{+}$production rates were generally highest in surface sediments (238 to $572 \mathrm{nmol} \mathrm{cm}^{-3} \mathrm{~d}^{-1}$ ) and low and stable in the deeper ( 6 to $10 \mathrm{~cm}$ ) sediment ( 42 to $60 \mathrm{nmol} \mathrm{cm}{ }^{-3} \mathrm{~d}^{-1}$ ). $\mathrm{NH}_{4}{ }^{+}$ production in the upper $2 \mathrm{~cm}$ sediment increased over the production cycle, from $238.1 \pm 30.5 \mathrm{nmol}$

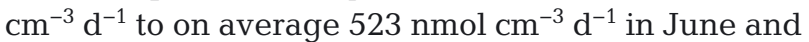
September (Fig. 6). $\mathrm{NH}_{4}{ }^{+}$production rates at the reference location were relatively low and stable (on

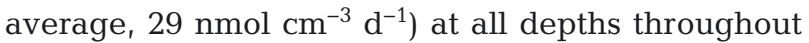
the study (Fig. 6). The average $\mathrm{C}: \mathrm{N}$ ratio of organic matter being mineralised, based on $\mathrm{TCO}_{2}$ and $\mathrm{NH}_{4}{ }^{+}$ production in jars, was markedly different at the 2 sampling locations. At the farming location, the C:N ratio was on average 4.1 (range: 1.9 to 8.5 ) and the lowest values were found in surface sediment, whereas at the reference location, the average $\mathrm{C}: \mathrm{N}$ ratio was 13.6 (range: 2.8 to 34.9). In contrast to $\mathrm{TCO}_{2}$ production and $\mathrm{SO}_{4}{ }^{2-}$ reduction rates, depth-integrated $\mathrm{NH}_{4}{ }^{+}$production rates increased over the production cycle at the farming location $\left(14.4 \pm 1.8 \mathrm{mmol} \mathrm{m}^{-2} \mathrm{~d}^{-1}\right.$ in March to $22.2 \pm 2.4 \mathrm{mmol} \mathrm{m}^{-2} \mathrm{~d}^{-1}$ in September) and decreased at the reference location (3.9 \pm $0.5 \mathrm{mmol} \mathrm{m}^{-2} \mathrm{~d}^{-1}$ in March to $2.4 \pm 2.0 \mathrm{mmol} \mathrm{m}^{-2} \mathrm{~d}^{-1}$ in September). However, during the fallowing period, $\mathrm{NH}_{4}{ }^{+}$production decreased at both the farming and reference locations $(20.5 \pm 3.0$ and $4.0 \pm 1 \mathrm{mmol}$ $\mathrm{m}^{-2} \mathrm{~d}^{-1}$, respectively).

\section{DISCUSSION}

\section{Sedimentation rates and organic enrichment}

At this well-flushed fish farm, $2340 \mathrm{t}$ of organic waste (primarily in the form of faeces) was released directly to the surrounding environment over the production cycle and at peak production (June to September 2010), daily sedimentation rates of POC ranged between 1.4 and $2.0 \mathrm{~g} \mathrm{~m}^{-2}$ at the farming location. These sedimentation rates are comparable to those measured by Kutti et al. (2007a) at another deep-water salmon farm (of similar biomass production, water depth, and current velocities) in Norway, and with predicted values calculated by Keeley et al. (2013a) at moderately enriched shallow-water salmon farms in New Zealand. However, compared to other salmonoid farms at shallower localities in the USA, the Faroe Islands, and Norway, sedimentation rates measured in the present study are up to 9 times lower during peak production (Findlay et al. 1995, Findlay \& Watling 1997, á Norði et al. 2011, Valdemarsen et al. 2012). This is despite the biomass 

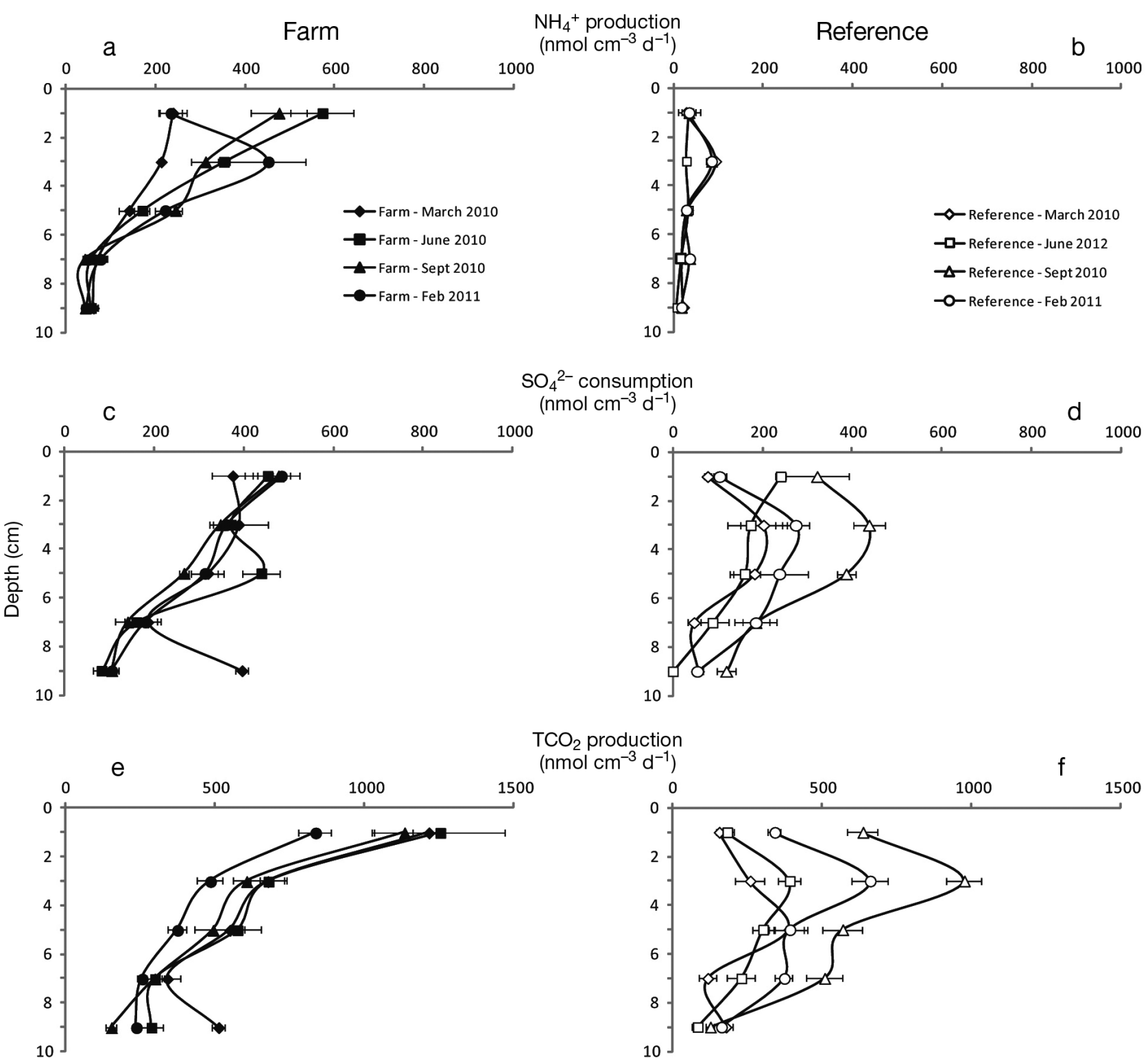

Fig. 6. Spatial distribution of microbial reaction rates based on jar experiments at the farming (solid symbols; upper panels) and reference (open symbols; lower panels) locations in March, June and September 2010: (a,b) total $\mathrm{CO}_{2}\left(\mathrm{TCO}_{2}\right)$ production, $(\mathrm{c}, \mathrm{d}) \mathrm{SO}_{4}{ }^{2-}$ consumption and $(\mathrm{d}, \mathrm{e}) \mathrm{NH}_{4}{ }^{+}$production. Error bars represent $\mathrm{SE}$ of the slope of linear regressions (metabolite concentration vs. time) corrected for sediment porosity

production of salmon during the present study being 10 times higher than the salmon farms in the USA (Findlay et al. 1995, Findlay \& Watling 1997), of similar biomass to the salmonid farms in the Faroe Islands (á Norði et al. 2011), and 50\% lower than that reported for another salmonoid farm studied in Norway (Valdemarsen et al. 2012). However, the combination of increased water depth $(>150 \mathrm{~m})$ and water currents $\left(0\right.$ to $\left.45 \mathrm{~cm} \mathrm{~s}^{-1}\right)$ at the farming location measured in the present study and also by Kutti et al. (2007a), compared with Findlay et al. (1995), Findlay \& Watling (1997), á Norði et al. (2011), and Valde- marsen et al. (2012), are likely driving the differences in dispersion and POC and TN sedimentation rates between these studies.

\section{Impact of organic enrichment on benthic fluxes and sediment biogeochemistry}

Organic enrichment (both carbon and nitrogen) of bottom sediments (0 to $10 \mathrm{~cm}$ ) was evident at the farming location, with a $50 \%$ higher carbon and nitrogen content of bottom sediments compared to 
the reference location at the start of the measurements (10 mo into the 18 mo production cycle). The organic enrichment at the farming location stimulated benthic fluxes of $\mathrm{O}_{2}, \mathrm{TCO}_{2}$, and $\mathrm{NH}_{4}^{+}$(5-6, 2.5-11.5 and 2-20 times higher, respectively) compared to the reference location, and indicated higher total benthic metabolism at the farming location over the production cycle. Similar responses to increased organic loading beneath fish farms have been documented earlier (Findlay \& Watling 1997, Holmer et al. 2002, Holmer \& Heilskov 2008, á Norði et al. 2011), but this has rarely been shown for deep-water farming locations. At both the studied locations, carbon and nitrogen content of bottom sediments remained relatively stable throughout the production cycle, despite 4 to 5 times increased deposition of organic carbon and nitrogen over the production cycle (Table 3), indicating that organic matter was either mineralised or resuspended. Kutti et al. (2007a) also demonstrated stable POC and TN concentrations in sediments over a production cycle at a fish farming location in western Norway with similar production (2950 tonnes). It was suggested that efficient microbial mineralisation, high secondary production by infauna and resuspension events were responsible for the stable POC and TN values (Kutti et al. 2007a). It is highly likely that the stable concentrations of organic matter in the sediments at the farming location was due to efficient microbial remineralisation of fish farm waste (Valdemarsen et al. 2009) and higher abundance (4.5 times increase) and biomass (1.5 times increase) of benthic fauna, coupled to resuspension events. Higher concentrations of POC and TN in the benthic traps (10 $\mathrm{m}$ above the bottom) compared to the pelagic traps (80 $\mathrm{m}$ above the bottom) and current velocities frequently exceeding free stream velocities $>9 \mathrm{~cm} \mathrm{~s}^{-1}$ that induce sediment erosion (Mitchener \& Torfs 1996, Cromey et al. 2002, CanalVerges et al. 2010) suggest that resuspension was highly likely at the farming location.

Mineralisation of organic carbon and nitrogen were measured by 2 different methods (i.e. fluxes and jar experiments) in the present study. In agreement with other studies, total mineralisation rates measured with both jar and flux techniques provided very similar results between flux measurements and production estimates, as demonstrated earlier (Aller \& Yingst 1980, Kristensen \& Hansen 1995, Valdemarsen et al. 2012). However, some discrepancies between nitrogen efflux and nitrogen production measurements were evident, with effluxes apparently underestimating $\mathrm{NH}_{4}{ }^{+}$production by 5 to $74 \%$. Given the low accumulation levels of $\mathrm{NH}_{4}{ }^{+}$within the sediments, it is plausible that the majority of the $\mathrm{NH}_{4}{ }^{+}$produced may have been removed by $\mathrm{NH}_{4}{ }^{+}$ oxidising processes (i.e. nitrification), as has been observed in other studies (Christensen et al. 2000, Carlsson et al. 2012). The stoichiometry between $\mathrm{O}_{2}$ uptake and $\mathrm{TCO}_{2}$ production based on effluxes was close to 1 during March and June 2010, indicating balanced sediment processes (Valdemarsen et al. 2009), as further indicated by stable biogeochemical pore water profiles. In contrast, during September 2010, the stoichiometry between $\mathrm{O}_{2}$ uptake and $\mathrm{TCO}_{2}$ production was closer to 2 for both measurement techniques. The stoichiometrically higher $\mathrm{O}_{2}$ consumption indicates that $\mathrm{O}_{2}$-consuming processes such as sulphide-oxide, metaloxide oxidation or nitrification occurred at higher rates in September 2010 when compared to the other samplings. At peak production (September 2010), mineralisation rates accounted for $\sim 75$ and $140 \%$, respectively, of the daily carbon and nitrogen emitted from the fish farm as waste products. Higher mineralisation rates of carbon (March 2010) and nitrogen (September 2010) at the farming location compared with the deposition rate of carbon and nitrogen during the same time period may be a result of the accumulated carbon and nitrogen in the sediments due to earlier fish farming activities (given the differences in sediment POC and TN between farming and reference locations), or alternatively a delay in mineralisation processes at the farming location (Valdemarsen et al. 2012). Given the stable seawater temperatures at both locations $\left(\sim 7\right.$ to $\left.8^{\circ} \mathrm{C}\right)$, temperature could not explain the differences in mineralisation rates, which were as such primarily fuelled by the influx of organic waste from the fish farm. In the present study, the stimulation of fluxes of $\mathrm{O}_{2}, \mathrm{TCO}_{2}$, and $\mathrm{NH}_{4}{ }^{+}$ at the farming location were on the lower end compared to other fish farm studies (Table 7).

Organic enrichment of sediments generally leads to stimulation of microbial sulphate reduction (Valdemarsen et al. 2009) and this was also observed in the present study. The rates of $\mathrm{TCO}_{2}$ production and $\mathrm{SO}_{4}{ }^{2-}$ consumption measured in jar experiments suggested a 50 to $200 \%$ increase in microbial sulphate reduction at the farming location compared to the reference location. The level of sulphate reduction was lower, however, than measured at other fish farms with similar or lower production (Table 7). Furthermore, it appeared that the stimulated sulphate reduction was not problematic at the studied farm, since $\mathrm{TH}_{2} \mathrm{~S}$ never accumulated to toxic levels in the sediment pore water. We also did not detect a significant accumulation of solid sulphur compounds 
(TRIS), which is frequently observed in heavily impacted sediments (Sanz-Lazaro et al. 2011, Valdemarsen et al. 2012). Based on sediment biogeochemical parameters, the sediments at the farming location were only moderately impacted by organic enrichment. The presence of oxidised Fe in sediments at the farming location also indicated that sediment redox conditions were only moderately affected compared to the reference location. Finally, we did not see an accumulation of organic matter in the sediments, which indicates that sedimentation of fish farm waste products was within sustainable limits (Valdemarsen et al. 2009, 2010). Thus despite the large size and production of the studied farm, it appeared that the water currents at the site were high enough to disperse the organic waste products over a sufficiently large area.

\section{Organic enrichment and fauna}

The effects of organic enrichment on benthic soft sediment systems and its associated fauna have been well documented, with increasing levels of organic enrichment resulting in a succession of benthic fauna from indigenous species to more opportunistic pollutant-tolerant species (Pearson \& Rosenberg 1978, Tsutsumi et al. 1991, Pearson \& Black 2001, Kutti et al. 2007b). In deepwater benthic marine ecosystems, food is a limiting resource, playing a key role in maintaining macrofauna populations. The results of the present study further demonstrate the impact of organic enrichment on the composition, abundance and biomass of benthic fauna in deepwater benthic systems. In this study, it appeared that the organic loading rates beneath the fish farm actually stimulated secondary production, as opposed to the dramatic detrimental effects of fish farming on benthic fauna observed in other studies (Findlay et al. 1995, Hargrave et al. 1997, Brooks et al. 2003). The high input of organic carbon to the seafloor during peak production in the present study ( $\left.6 \mathrm{~g} \mathrm{POC} \mathrm{m}^{-2} \mathrm{~d}^{-1}\right)$ was sufficient to support a standing benthic biomass of $\sim 60 \mathrm{~g}$ ashfree dry weight $\mathrm{m}^{-2}$, a 10 times higher standing biomass of benthic fauna relative to the reference station at the start of the production cycle. Similar stimulatory effects of secondary benthic production from fish farming in deep-water Norwegian fjord systems were also documented by Kutti et al. $(2007 \mathrm{a}, \mathrm{b})$, where an influx of $\sim 4 \mathrm{~g} \mathrm{POC} \mathrm{m}^{-2} \mathrm{~d}^{-1}$

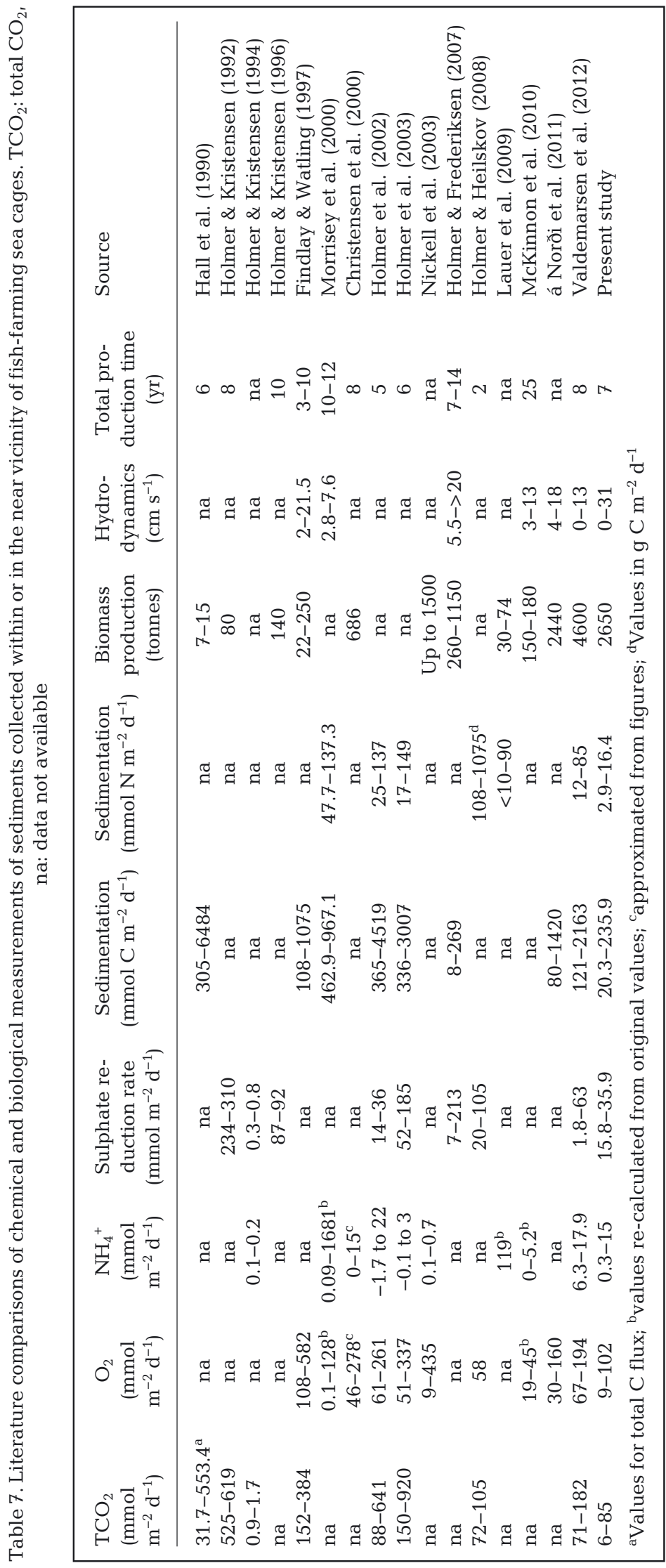


supports a standing biomass of $\sim 51 \mathrm{~g}$ ash-free dry weight $\mathrm{m}^{-2}$ of benthic fauna. However, compared to fauna-rich habitats, the biomass of infauna in the present study was considerably lower than that reported by Keeley et al. (2013b) from low- (124 g $\left.\mathrm{m}^{-2}\right)$ and high- $\left(378 \mathrm{~g} \mathrm{~m}^{-2}\right)$ flow shallow-water salmon farms in New Zealand.

The shift to more opportunistic dominated fauna at the farming location was pronounced, with increased organic loading over the production cycle (i.e. during peak production). Despite the richness of fauna remaining stable at the farming location, there was a clear decrease in diversity. Decreased diversity was driven by the pollutant-tolerant polychaetes Capitella capitata, Heteromastus filiformis and Paramphinome jeffreysii, and the bivalves Abra nitida and Thyasira sarsii, which occurred in high abundances during peak production at the farming location. These opportunistic species have previously been demonstrated to tolerate deep-water soft sediment habitats organically enriched through aquaculture (Kutti et al. 2007b), and are probably characteristic species to tolerate organically enriched sediments in deepwater habitats. The opportunistic polychaete C. capitata is a pollutant-tolerant species that generally dominates benthic fauna communities in shallow soft sediments organically enriched by fish farming (Hargrave et al. 1993, Findlay et al. 1995, Nickell et al. 2003), and during the present study, it occurred at similar abundances to those measured in these shallower studies. However, infauna populations documented under salmon farms in New Zealand far exceed the abundance measurements measured in the present study (Keeley et al. 2013b). Furthermore, the polychaetes $H$. filiformis and $P$. jeffreysii have also been documented in organically enriched deepwater soft sediment habitats (Rosenberg 1995). Therefore, the concurrence of C. capitata, $H$. filiformis and $P$. jeffreysii provides strong evidence of the impact of organic enrichment on community structure in deep soft-sediment habitats. Some of the dominant polychaete fauna present at the reference locations $(P$. jeffreysii, Myriochele oculata, Kelliella abyssicola, $A$. nitida) have also been found in moderately enriched environments adjacent to fish farms (Kutti et al. 2007b, Lin \& Bailey-Brock 2008). This further suggests that the reference location selected for the present study, situated $700 \mathrm{~m}$ downstream of the fish farm, was moderately enriched during the study.

The increasing abundance and biomass of benthic macrofauna at the farming location most likely played an important role in the mineralisation of the organic waste settling to the seafloor. Previous stud- ies have provided clear evidence of the importance of macrofauna in enhancing mineralisation of organic material in sediments through bio-irrigation and sediment reworking (Heilskov \& Holmer 2001, Heilskov et al. 2006, Valdemarsen et al. 2010). The opportunistic polychaetes present in the present study probably played a critical role in maintaining the stable sediment biogeochemistry and carbon and nitrogen concentrations measured in the sediments.

\section{The effects of fallowing}

The ability of recipient benthic environments to recover from enrichment of organic effluents from fish farming and to determine the level of recovery necessary before beginning a new production cycle is a matter of high debate within the research community globally (Brooks et al. 2004, Macleod et al. 2006, Lin \& Bailey-Brock 2008, Aguado-Giménez et al. 2012). The holistic approach used in the present study provides multiple lines of evidence that a coastal fjord system can respond rapidly to the onset and cessation of a large input of organic matter. The results from this study illustrate that at moderate impact levels, a 2.5 mo fallowing period can result in rapid recovery of benthic fluxes $\mathrm{O}_{2}, \mathrm{TCO}_{2}$ and $\mathrm{NH}_{4}{ }^{+}$), and a decrease in abundance and biomass of benthic fauna. However, during this short fallowing period, benthic fluxes and the structure, abundance and diversity of benthic infauna were still elevated when compared to pre-farming conditions (i.e. reference) and other reference locations not impacted through fish farming activities in Norwegian fjords (Kutti et al. 2007b, Valdemarsen et al. 2012). Other studies investigating the recovery of soft sediment habitats have reported complete biological remediation within a mere 6 mo of fallowing onset (Brooks et al. 2003), while other studies have demonstrated that more than 6 mo and in some cases as long as 3 to $4 \mathrm{yr}$ are needed for soft sediment habitats to fully recover post-farming (Johannessen et al. 1994, Brooks et al. 2004, Macleod et al. 2006, 2007, Lin \& Bailey-Brock 2008, Aguado-Giménez et al. 2012).

\section{CONCLUSIONS}

Given the larger biomass (3000 t) production of this modern fish-farm facility coupled with an 18 mo production cycle, it is reasonable to expect moderate benthic impacts within the surrounding area of the fish farm. This study reinforces that increasing the 
water depth below fish farms and maintaining adequate water currents will enhance waste dispersion, thus minimising localised organic loading events to benthic habitats (Stigebrandt et al. 2004). The results presented here demonstrate that over a production cycle at current farming levels, organic enrichment from fish farming activities at this particular location increased benthic metabolism, stimulated benthic secondary production and changed dominant metabolic pathways. However, stable and comparable sediment biogeochemical pore water chemistry between farming and reference locations (even compared to other fjord reference locations; Valdemarsen et al. 2012) and also over the production cycle suggests that organic loading was maintained within the assimilative capacity of the receiving environment. This is further supported by the fact fish farming has been ongoing at this location since 2003, producing in excess of $10000 \mathrm{t}$ of Atlantic salmon, and the sediment biogeochemical status was not changed considerably. Provided correct environmental conditions (i.e. current velocities and water depth) are coupled to correct farm management practices (i.e. husbandry practices), acceptable loading and accumulation of organic material to benthic systems can be achieved.

Acknowledgements. We acknowledge the crew of the RV 'Brattstrøm' for their assistance in deploying sediment traps and the recovery of box-core samples. Thank you to Bremnes Seashore fish farming company and the farm manager for their valued assistance in sample collection and deployment of sediment traps and access to the valuable farm management data used in this study. Furthermore, thank you to Cathinka Krogness and the technicians in the chemistry lab at IMR and University of Odense, Denmark for sample preparation and analysis. Thank you to Per Johannessen at the University of Bergen for identification of infauna. Also, thank you to 3 anonymous referees who provided constructive comments to improve the manuscript. This research presented here was funded by the Norwegian Research Council (project \#190474) awarded to A.E. T.V. was also supported by grant no. 09-063190/DSF.

\section{LITERATURE CITED}

Aguado-Giménez F, Piedecausa MA, Gutierrez JM, GarciaCharton JA, Belmonte A, Garcia-Garcia B (2012) Benthic recovery after fish farming cessation: a 'beyond-BACI' approach. Mar Pollut Bull 64:729-738

Aller RC, Yingst JY (1980) Relationships between microbial distributions and the anaerobic decomposition of organicmatter in surface sediments of Long-Island Sound, USA. Mar Biol 56:29-42

>á Norði G, Glud RN, Gaard E, Simonsen K (2011) Environmental impacts of coastal fish farming: carbon and nitrogen budgets for trout farming in Kaldbaksfjørður (Faroe Islands). Mar Ecol Prog Ser 431:223-241

Aure J (2013) Aquaculture and oxygen in Hardangerfjord basin. Fisken og havet, Særnummer 1-2013

Brooks KM, Mahnken CVW (2003) Interactions of Atlantic salmon in the Pacific northwest environment: II. organic wastes. Fish Res 62:255-293

> Brooks KM, Stierns AR, Mahnken CVW, Blackburn DB (2003) Chemical and biological remediation of the benthos near Atlantic salmon farms. Aquaculture 219: 355-377

> Brooks KM, Stierns AR, Backman C (2004) Seven year remediation study at the Carrie Bay Atlantic salmon (Salmo salar) farm in the Broughton Archipeligo, British Columbia, Canada. Aquaculture 239:81-123

Canal-Verges P, Vedel M, Valdemarsen T, Kristensen E, Flindt MR (2010) Resuspension created by bedload transport of macroalgae: implications for ecosystem functioning. Hydrobiologia 649:69-76

Canfield DE (1989) Reactive iron in marine sediments. Geochim Cosmochim Acta 53:619-632

Carlsson MS, Engström P, Lindahl O, Ljungqvist L, Petersen JK, Svanberg L, Holmer M (2012) Effects of mussel farms on the benthic nitrogen cycle on the Swedish west coast. Aquacult Environ Interact 2:177-191

> Carroll ML, Cochrane S, Fieler R, Velvin R, White P (2003) Organic enrichment of sediments from salmon farming in Norway: environmental factors, management practices, and monitoring techniques. Aquaculture 226: 165-180

> Christensen PB, Rysgaard S, Sloth NP, Dalsgaard T, Schwærter S (2000) Sediment mineralization, nutrient fluxes, denitrification and dissimilatory nitrate reduction to ammonium in an estuarine fjord with sea cage trout farms. Aquat Microb Ecol 21:73-84

Clarke KR (1993) Non-parametric multivariate analysis of changes in community structure. Austral Ecol 18: $117-143$

Cline JD (1969) Spectrophotometric determination of hydrogen sulphide in natural waters. Limnol Oceanogr 14: 454-458

Cromey CJ, Nickell TD, Black KD, Provost PG, Griffiths CR (2002) Validation of a fish farm waste re-suspension model by use of a particulate tracer discharged from a point source in a coastal environment. Estuaries 25: 916-929

FAO (Food and Agriculture Organization of the United Nations) (2012) World review of fisheries and aquaculture. In: Grainger R (ed) The state of world fisheries and aquaculture. FAO, Rome, p 3-100

> Findlay RH, Watling L (1997) Prediction of benthic impact for salmon net-pens based on the balance of benthic oxygen supply and demand. Mar Ecol Prog Ser 155:147-157

- Findlay RH, Watling L, Mayer LM (1995) Environmental impact of salmon net-pen culture on marine benthic communities in Maine: a case study. Estuaries 18:145-179

Fossing H, Jørgensen BB (1989) Measurement of bacterial sulfate reduction in sediments - evaluation of a single step chromium reduction method. Biogeochemistry 8: 205-222

Gullestad P, Bjørgo S, Eithun I, Ervik A and others (2011) Effektiv bærehraftig arealbruk i havbruksnæringenareal til beglær. Rapport fra Ekspertutvalg til Fiskeri og Kystdepartement. Institute of Marine Research, Bergen

Hall POJ, Aller RC (1992) Rapid, small-volume, flow injection analysis for $\mathrm{\Sigma CO}_{2}$ and $\mathrm{NH}_{4}{ }^{+}$in marine and freshwaters. Limnol Oceanogr 37:1113-1119

Hall POJ, Anderson LG, Holby O, Kollberg S, Samuelsson 
MO (1990) Chemical fluxes and mass balances in a marine fish cage farm. I. Carbon. Mar Ecol Prog Ser 61:61-73

Hansen PK, Kryvi H (2009) Regulation of Norwegian netcage fish farming. In: FAO/Regional Commission for Fisheries. Report of the Regional Technical Workshop on Sustainable Marine Cage Aquaculture Development. Muscat, Sultanate of Oman, 25-26 January 2009. FAO Fish Aquacult Rep 892:77-90

Hargrave BT, Duplisea DE, Pfeiffer E, Wildish DJ (1993) Seasonal changes in benthic fluxes of dissolved oxygen and ammonium associated with marine cultured Atlantic salmon. Mar Ecol Prog Ser 96:249-257

Hargrave BT, Phillips GA, Doucette LI, White MJ, Milligan TG, Wildish DJ, Cranston RE (1997) Assessing benthic impacts of organic enrichment from marine aquaculture. Water Air Soil Pollut 99:641-650

- Hargrave BT, Holmer M, Newcombe CP (2008) Towards a classification of organic enrichment in marine sediments based on biogeochemical indicators. Mar Pollut Bull 56: 810-824

Heilskov AC, Holmer M (2001) Effects of benthic fauna on organic matter mineralisation in fish farm sediments: importance of size and abundance. ICES J Mar Sci 58: 427-434

Heilskov AC, Alperin M, Holmer M (2006) Benthic fauna bio-irrigation effects on nutrient regeneration in fish farm sediments. J Exp Mar Biol Ecol 339:204-225

Holmer M (2010) Environmental issues of fish farming in offshore waters: perspectives, concerns and research needs. Aquacult Environ Interact 1:57-70

> Holmer M, Frederiksen MS (2007) Stimulation of sulfate reduction rates in Mediterranean fish farm sediments inhabited by the seagrass Posidonia oceanica. Biogeochemistry 85:169-184

> Holmer M, Heilskov AC (2008) Distribution and bioturbation effects of the tropical alpheid shrimp Alpheus macellarius in sediments impacted by milkfish farming. Estuar Coast Shelf Sci 76:657-667

Holmer M, Kristensen E (1992) Impact of marine fish cage farming on metabolism and sulfate reduction of underlying sediments. Mar Ecol Prog Ser 80:191-201

> Holmer M, Kristensen E (1994) Organic matter mineralization in an organic-rich sediment: experimental stimulation of sulfate reduction by fish food pellets. FEMS Microbiol Ecol 14:33-44

- Holmer M, Kristensen E (1996) Seasonality of sulfate reduction and pore water solutes in a marine fish farm sediment: the importance of temperature and sedimentary organic matter. Biogeochemistry 32:15-39

> Holmer M, Marba N, Terrados J, Duarte CM, Fortes MD (2002) Impacts of milkfish (Chanos chanos) aquaculture in carbon and nutrient fluxes in the Balinao area, Philippines. Mar Pollut Bull 44:685-696

Holmer M, Duarte CM, Heilskov A, Olesen B, Terrados J (2003) Biogeochemical conditions in sediments enriched by organic matter from net-pen fish farms in the Bolinao area, Philippines. Mar Pollut Bull 46:1470-1479

Holmer M, Wildish D, Hargrave B (2005) Water pollution environmental effects of marine finfish aquaculture. In: Hargrave B (ed) Handbook of environmental chemistry, Vol 5. Springer, Berlin, p 181-206

> Johannessen PJ, Botnen HB, Tvedten ØF (1994) Macrobenthos: before, during and after a fish farm. Aquacult Res 25:55-66

Keeley NB, Cromey CJ, Goodwin EO, Gibbs MT, Macleod
CM (2013a) Predictive depositional modelling (DEPOMOD) of the interactive effect of current flow and resuspension on ecological impacts beneath salmon farms. Aquacult Environ Interact 3:275-291

Keeley NB, Forrest BM, Macleod CK (2013b) Novel observations of benthic enrichment in contrasting flow regimes with implications for marine farm monitoring and management. Mar Pollut Bull 66:105-116

Kerouel R, Aminot A (1997) Fluorometric determination of ammonia in sea and estuarine waters by direct segmented flow analysis. Mar Chem 57:265-275

> Kristensen E, Andersen FO (1987) Determination of organic carbon in marine sediments: a comparison of two CHN analyzer methods. J Exp Mar Biol Ecol 109:15-23

> Kristensen E, Hansen K (1995) Decay of plant detritus in organic-poor marine sediment: production rates and stoichiometry of dissolved $\mathrm{C}$ and $\mathrm{N}$ compounds. J Mar Res 53:675-702

Kutti T, Ervik A, Hansen KP (2007a) Effects of organic effluents from a salmon farm in a fjord system. I. Vertical export and dispersion processes. Aquaculture 262: 367-381

> Kutti T, Hansen KP, Ervik A, Høisæter T, Johannessen P (2007b) Effects of organic effluents from a salmon farm on a fjord system. II. Temporal and spatial patterns in infauna community composition. Aquaculture 262: 355-366

> Kutti T, Ervik A, Høisæter T (2008) Effects of organic effluents from a salmon farm on a fjord system. III. Linking deposition rates of organic matter and benthic productivity. Aquaculture 282:47-53

> Lauer PR, Fernandes M, Fairweather PG, Tanner J, Cheshire A (2009) Benthic fluxes of nitrogen and phosphorus at southern bluefin tuna Thunnus maccoyii sea-cages. Mar Ecol Prog Ser 390:251-263

Lin DT, Bailey-Brock JH (2008) Partial recovery of infaunal communities during a fallow period at an open-ocean aquaculture. Mar Ecol Prog Ser 371:65-72

Lovley DR, Phillips EJP (1987) Rapid assay for microbially reducible ferric iron in aquatic sediments. Appl Environ Microbiol 53:1536-1540

Macleod CK, Moltschaniwskyj NA, Crawford CM (2006) Evaluation of short-term fallowing as a strategy for the management of recurring organic enrichment under salmon cages. Mar Pollut Bull 52:1458-1466

> Macleod CK, Moltschaniwskyj NA, Crawford CM, Forbes SE (2007) Biological recovery from organic enrichment: some systems cope better than others. Mar Ecol Prog Ser 342:41-53

> McKinnon AD, Trott LA, Brinkman R, Duggan S, Castine S, O'Leary RA, Alongi DM (2010) Seacage aquaculture in a World Heritage Area: the environmental footprint of a barramundi farm in tropical Australia. Mar Pollut Bull 60: 1489-1501

> Mitchener H, Torfs H (1996) Erosion of mud/sand mixtures. Coast Eng 29:1-25

> Morrisey DJ, Gibbs MM, Pickmere SE, Cole RG (2000) Predicting impacts and recovery of marine-farm sites in Stewart Island, New Zealand, from the Findlay-Watling model. Aquaculture 185:257-271

> Nickell LA, Black KD, Hughes DJ, Overnell J and others (2003) Bioturbation, sediment fluxes and benthic community structure around a salmon cage farm in Loch Creran, Scotland. J Exp Mar Biol Ecol 285-286:221-233 Norwegian Directorate of Fisheries (2012) Aquaculture sta- 
tistics: Atlantic salmon and rainbow trout. www. fiskeridir.no/english/statistics/norwegian-aquaculture/ aquaculture-statistics/atlantic-salmon-and-rainbow-trout (accessed 30 Jul 2013)

Pearson TH, Black KD (2001) The environmental impacts of marine fish cage culture. In: Black KD (ed) Environmental impacts of aquaculture. Sheffield Academic Press, Sheffield, p 1-31

Pearson TH, Rosenberg R (1978) Macrobenthic succession in relation to organic enrichment of the marine environment. Oceanogr Mar Biol Annu Rev 16:229-311

Quinn GP, Keough MJ (2002) Experimental design and data analysis for biologists. Cambridge University Press, Cambridge

Rosenberg R (1995) Benthic marine fauna structured by hydrodynamic processes and food availability. Neth J Sea Res 34:303-317

Sanz-Lazaro C, Valdemarsen T, Marin A, Holmer M (2011) Effects of temperature on biogeochemistry of marine organic enriched systems: implications in a global warming scenario. Ecol Appl 21:2664-2677

Stigebrandt A, Aure J, Ervik A, Hansen KP (2004) Regulating the local environmental impact of intensive marine fish farming III. A model for estimation of the holding capacity in the Modeling-Ongrowing fish farm-Monitoring system. Aquaculture 234:239-261

Stookey LL (1970) Ferrozine - a new spectrophotometric reagent for iron. Anal Chem 42:779-781

Editorial responsibility: Catriona MacLeod, Hobart, Australia
Strain PM, Hargrave BT (2005) Salmon aquaculture, nutrient fluxes and ecosystem processes in southwestern New Brunswick. In: Hargrave BT (ed) Environmental effects of marine finfish aquaculture. Springer, Berlin, p 29-57

Tsutsumi H, Kikuchi T, Tanaka M, Higashi T, Imasaka K, Miyazaki M (1991) Benthic faunal succession in a cove organically polluted by fish farming. Mar Pollut Bull 23: 233-238

Underwood AJ (1981) Techniques of analysis of variance in experimental marine biology and ecology. Oceanogr Mar Biol Annu Rev 19:513-605

> Valdemarsen T, Kristensen E (2005) Diffusion scale dependent change in anaerobic carbon and nitrogen mineralization: true effect or experimental artifact? J Mar Res 63: 645-669

> Valdemarsen T, Kristensen E, Holmer M (2009) Metabolic threshold and sulfide-buffering in diffusion controlled marine sediments impacted by continuous organic enrichment. Biogeochemistry 95:335-353

Valdemarsen T, Kristensen E, Holmer M (2010) Sulfur, carbon, and nitrogen cycling in faunated marine sediments impacted by repeated organic enrichment. Mar Ecol Prog Ser 400:37-53

Valdemarsen T, Bannister RJ, Hansen PK, Holmer M, Ervik A (2012) Biogeochemical malfunctioning in sediments beneath a deep-water fish farm. Environ Pollut 170: $15-25$

Submitted: August 1, 2013; Accepted: January 16, 2014 Proofs received from author(s): February 21, 2014 